\title{
Türkiye'de Cari Sağlık Harcaması, Ekonomik Büyüme ve Doğumda Beklenen Yaşam Süresinin ADRL Sınır Testi ile Analizi
}

Funda AKBAL $L^{*}$

Öz: Sağl1k ekonomisinde sağl1k hizmetlerinin sunumu, sunulan sağl1k hizmetlerinin finansmanı, yaşam süresinin uzamasına bağlı olarak sağlık problemlerinin artması, ortaya çıkan hastalıkların öngörülememesi, sağl1k alanında teknolojik gelişmeler gibi faktörler ile sağlık hizmetlerinin talep ve arz yapısı, diğer mal ve hizmetlere göre farklılık göstermektedir. Bu çalışmanın amacı, Türkiye'de 1980-2018 yılları arasında ekonomik büyüme, cari sağlık harcamasının gayri safi yurt içi hasılaya (GSYİH) oranı ile doğumda beklenen yaşam süresine ait değişkenlerin aralarındaki ilişkiyi ARDL sınır testi ile incelemektir. ARDL $(4,3,3)$ sınır testi uzun dönem katsayı sonuçlarına göre, doğumda beklenen yaşam süresindeki \%1'lik artışın, cari sağlık harcamasının gayri safi yurtiçi hasılaya oranını yaklaşı \%31.15 oranda arttırdığı ve bu sonucun istatiksel olarak anlamlı olduğu tespit edilmiştir. Ayrıca ekonomik büyümedeki \%1'lik artışın, cari sağlık harcamasının GSYIH'ya oranını yaklaşık $\% 0.28$ arttırdığ 1 ve bu sonucun istatiksel olarak anlamlılığ ARDL $(4,3,3)$ hata düzeltme modelinde hesaplanan hata terimi katsay sonucuna göre, kısa dönemde oluşan dengesizliklerin yaklaşık 4 yıl sonunda uzun dönem denge değerine doğru yakınsayacağı sonucu çıkarılır. Analiz sonucunda, doğumda beklenen yaşam süresi ile ekonomik büyüme değişkenlerinin cari sağlık harcamasının gayri safi yurtiçi hasılaya etkisi incelenmiş ve değişkenler arasında uzun dönemli bir ilişkinin olduğu sonucuna varılmıştır.

Anahtar Kelimeler: ARDL Sinır Testi, Cari Sağlık Harcaması, Ekonomik Büyüme.

\section{Current Health Expenditure, Economic Growth and Life Expectancy at Birth in Turkey: An Analysis with ARDL Bound Test}

Abstract: Factors such as the provision of health services in the health economy, the financing of health services, the increase in health problems due to prolongation of life, the unpredictability of emerging diseases, technological developments in the field of health, and the demand and supply structure of health services differ from other goods and services. The aim of this study is to examine the relationship between economic growth between 1980 and 2018, the ratio of current health expenditure to gross domestic product (GDP) and life

\footnotetext{
* Doktora Öğrencisi, Üsküdar Üniversitesi Sağlık Yönetimi Bölümü, İstanbul/Türkiye. e-mail: funda_akbal_44@hotmail.com

ORCID: 0000-0003-2422-5805
}

Geliş Tarihi: 15 Şubat $2021 \quad$ Kabul Tarihi: 08 Haziran 2021

Received: 15 February $2021 \quad$ Accepted: 08 June 2021

Bu makaleye atıf için / To cite this article: Akbal, F. (2021). Türkiye'de Cari Sağlık Harcamas1, Ekonomik Büyüme ve Doğumda Beklenen Yaşam Süresinin ADRL Sınır Testi ile Analizi Medeniyet Araştırmaları Dergisi, 6(1), 179-203.

Doi: $10.52539 / \mathrm{mad} .880739$ 
expectancy at birth variables with the ARDL boundary test. According to the long-term coefficient results of the ARDL $(4,3,3)$ limit test, it was determined that a $1 \%$ increase in life expectancy at birth increased the ratio of current health expenditure to gross domestic product by approximately $31,15 \%$. and this result is statistically significant. In addition, a $1 \%$ increase in economic growth increased the ratio of current health expenditures to GDP by approximately $0.28 \%$, and the statistical significance of this result was tested. According to the error correction coefficient calculated in the ARDL $(4,3,3)$ error correction model, it is concluded that short-term imbalances will approach the long-term equilibrium value at the end of approximately 4 years. In the analysis, the effects of economic growth variables on life expectancy at birth and current health expenditures on gross domestic product were examined and it was concluded that there was a long-term relationship between the variables.

Keywords: ARDL Limit Test, Current Health Expenditure, Economic Growth.

\section{Giriş}

Refah devletinde, sağlığın kamu kesimince en önemli harcama kalemlerinden olduğu devletin sosyal devlet anlayışına dayalı hem finansman hem üretim açısından özel sektörün yanında, sağlık hizmetlerinin sunumunu giderek artan bir şekilde üstlendiği görülmektedir (Yurdadoğ, 2007: 591).

$\mathrm{Bu}$ anlayış temelinde, Türkiye'de toplam sağlik harcamaları Türkiye İstatistik Kurumu (TÜIK) verilerine göre, genel devlet ve özel sektör sağlık harcamaları Şekil 1'de sunulmaktadır.

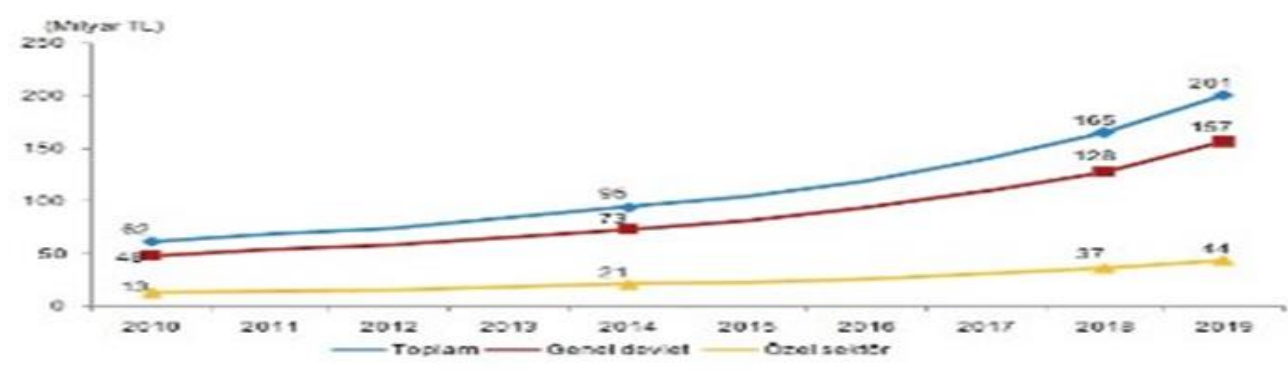

Şekil 1: Sağlık Harcamaları 2010,2019

Kaynak: https://data.tuik.gov.tr/Saglik-Harcamalari-Istatistikleri-2019

Şekil 1'de toplam sağlık harcamalarının yıllara göre artışında, genel sağlık sigortası kapsamında kamu sağlık hizmet sunumu yapan hizmet sunucularının, sunulan sağlık hizmeti karşılığında sağlık harcamalarının TÜIKK istatistiklerine göre \%51.7'si Sosyal Güvenlik Kurumu (SGK) tarafindan finanse edildiği için genel devlet sağlık harcamasında büyük artış olduğu görülmektedir. Sağlık harcamalarında, sağlık hizmetlerinin finansman yapısına göre belirlenen sağlık sistem modelinde alınan hizmet sunumunun karşılığında sağlık harcamalarının finansmanı en fazla oranla fonda toplanan gelir/prim olarak karşılandığı için toplam sağlık harcamasında, özel sektör oranı genel devlet oranı ile karşılaştırıldığında aralarındaki farkın büyük bir oranla açıldığı görülmektedir. 
Sağlık hizmeti sunucularına göre toplam sağlık harcamaları, cari sağlık harcamalarının alt fonksiyonları ile yatırım harcamaları ve toplam sağlık harcamaları ile cari sağlı harcamalarının GSYİH'ya oranları Tablo 1'de gösterilmektedir.

Tablo 1: Sağlık Hizmeti Sunucularına Göre Sağlık Harcamaları 2018, 2019.

\begin{tabular}{lllll}
\hline & \multicolumn{3}{c}{ (MilyonTL) } \\
\hline Toplam Sağlık Harcaması & 2018 & Pay (\%) & 2019 & Pay (\%) \\
Cari Sağlık Harcaması & $\mathbf{1 6 5 2 3 4}$ & $\mathbf{1 0 0}$ & $\mathbf{2 0 1} \mathbf{0 3 1}$ & $\mathbf{1 0 0}$ \\
Hastaneler & $\mathbf{1 5 4} \mathbf{9 9 8}$ & $\mathbf{9 3 , 8}$ & $\mathbf{1 8 7 ~ 6 7 3}$ & $\mathbf{9 3 , 4}$ \\
Evde Hemşirelik Bakımı & 80701 & 48,8 & 96883 & 48,2 \\
Ayakta Bakım Sunanlar & 1 & 0 & 1 & 0 \\
Perakende Satış ve Diğer Tıbbı Malzeme Sunanlar & 41424 & 25,1 & 51922 & 25,8 \\
Halk Sağlığı Programlarının Sunumu ve Yönetimi & 7324 & 4,4 & 8884 & 4,4 \\
Genel Sağlık Yönetimi ve Sigortası & 931 & 0,6 & 949 & 0,5 \\
Sınıflandırılamayan Diğer Kategori & 4501 & 2,7 & 5065 & 2,5 \\
Yatırım Sağlı Harcaması & $\mathbf{1 0 2 3 6}$ & $\mathbf{6 , 2}$ & $\mathbf{1 3 ~ 3 5 7}$ & $\mathbf{6 , 6}$ \\
\hline Toplam Sağlık Harcamasının GSYİH’ya Oranı & & 4,4 & & 4,7 \\
Cari Sağlık Harcamasının GSYİH’ya Oranı & & 4,1 & & 4,3 \\
\hline \hline
\end{tabular}

Kaynak: TÜİK, https://data.tuik.gov.tr/Saglik-Harcamalari-Istatistikleri-2019

Tablo 1'de, sağlık hizmeti sunucularına göre toplam sağlık harcamaları oranları verilmiştir. TÜIK 2019 istatistiklerine göre cari sağlık harcaması $\% 93,4$, yatırım harcaması $\% 6,6$ oranları ile toplam sağlık harcamalarını oluşturmaktadır. Toplam sağlık harcamasının gayri safi yurtiçi hasılaya oranı $\% 4,7$ olduğu ve cari sağlık harcamasının gayri safi yurtiçi hasılaya oranı $\% 4,3$ olduğu görülmektedir.

Sağlık hizmeti sunucularına göre cari sağlık harcaması; evde hemşirelik bakımı, hastaneler, ayakta bakım sunanlar, genel sağlı yönetimi ve sigortası, halk sağlığı programlarının sunumu ve yönetimi, perakende satış ve diğer tıbbı malzeme sunanalar ile sinıflandırılamayan diğer kategorileri kapsamaktadır. Tablo 1'de sağlık hizmeti sunucularına göre sağlık hizmet sunumu yapan hastanelerin, 2019 yılında \%48,2 oranla cari sağlık harcaması içinde en fazla payı almaktadır. Sağlık hizmet sunumu yapan hizmet sunucuları, üçüncü taraf ödeyici ve hasta/birey ile sağlık üçgeni oluşmaktadır.

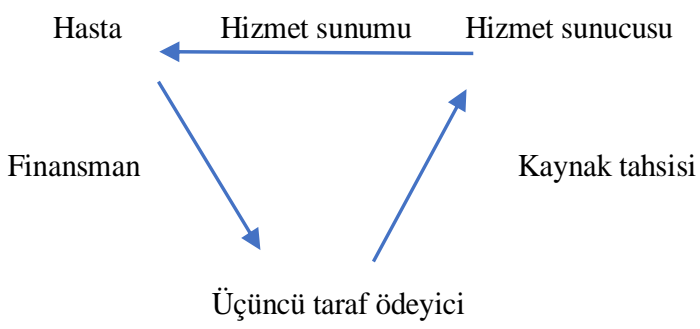

Şekil 2: Sağlık Sistem Üçgeni 
Kaynak: Mossialos, Elias, ve Sarah M. S. Thomson. 2002. "Voluntary Health Insurance in the European Union: A Critical Assessment" makalesinden alınmıştır.

Kaynak aktarımı olarak adlandırılan sağlık üçgeninde birinci taraf olan hastaların, aldıkları sağlık hizmetlerinin bedelini hizmet sunumunu yapan ve ikinci taraf olan hizmet sunucusuna ya doğrudan ödeme yaparak yani kaynak akışı doğrudan birey ve ikinci taraf arasında basit transfer olarak ya da alınan hizmet sunumunun karşılığında üçüncü taraf ödeyicilerinin, hizmet sunucularına yaptıkları ödeme ile karmaşık transfer şeklinde olmaktadır. Karşılaşılan sağlık sorunları ve hastalıkların finansal risklerine karşı bireyleri/hastaları güvence altına almak için sağlık sistemleri, üçüncü taraf ödeyicileri geliştirmiştir. Özel kuruluş ve kamu kuruluş olan üçüncü taraf ödeyici, sağlik hizmetlerini finanse edebilmek için kapsam altına aldığı nüfustan dolaylı olarak veya doğrudan gelir toplamaktadır. Toplanan gelir ya üçüncü taraf olmadan doğrudan ödedikleri hizmet bedelini hastalara geri ödeme ya da sunulan sağlik hizmetinin karşılığ olarak hizmet sunucularına aktarılmaktadır. Sağlık sisteminde üçüncü taraf ödeme mekanizmasının geliştirilmesindeki ana unsur sağlık problemlerinin ortaya çıkma süresinin belirsizliğinden dolayı bireylerin karşılaşabileceği finansal riskin paylaşılmasını ve yeniden bireyler arasında dağıtılmasını sağlamaktır (Mossialos ve Thomson, 2002: 2-3).

Sağlık sistemi finansmanı başlıca gelir toplama, fon havuzlama ve sağlık hizmeti satın alma olarak işlevsel bileşenlerine ayrılır (Güvercin vd., 2016: 84). Gelir toplama süreci, kimin ödediği, ödemenin yapılması ve kimin tahsil ettiği ile ilgilidir. Finansman mekanizmaları; vergilendirme, sosyal sigorta primleri, özel sigorta primleri, bireysel tasarruflar, cepten yapılan ödemeler ve krediler ve bağışları içerir (Şeyma Koca, 2018: 5045). Fon havuzlama hizmet sunucuları için sağlık hizmetleri talebini destekleyip fon akışını garantilediğinden dolayı yeni yatırımlara yönelmeyi teşvik etmekte ve belirsizliği azaltmaktadır (Yenimahalleli Yaşar, 2010: 32). Sağlık hizmeti satın alma işlevi ise sağllk hizmet sunucularına fonda toplanan gelirlerin, sunulan sağlık hizmetinin karşılığında sağlık hizmet sunucularına aktarılmasıdır (Güvercin vd., 2016: 83).

Ülkelerin finansman yapılarına göre uyguladıkları sağlık sistem modelleri, her ülke için değişiklik göstermektedir. Literatürde sıklıkla sağlık sistemleri sinıflandırmasında, Beveridge veya Ulusal Sağlık Hizmetleri; Bismarck veya Sosyal Sağlık Sigortası; Özel Sağlık Sigortası veya Liberal modellerinin kullanıldığı görülmektedir (Yılmaz, 2018: 192). Sağlık harcamalarında ülkelerin ekonomik durumu ve politik tercihleri başta olmak üzere sağlık hizmetlerinin finansmanına göre sağlı sistem modelleri belirlenmektedir. Sunulan sağlık hizmetlerinin karşılığında sağlık sunucularına kaynak aktarımı ile sağlık sistemindeki süreç bu doğrultuda gelişmektedir. Aynı sağlık sistem modelini uygulayan ülkelerde sağlık hizmetinin finansman yapısında farklılıklar olduğu görülmektedir. Ülkelerde sağlık hizmetlerinin finansmanına göre belirlenen sağlık sistem modelleri Tablo 2'de sunulmaktadır. 
Tablo 2: Sağlık Sistem Modelleri

\begin{tabular}{|l|l|l|l|}
\hline & Beveridge Modeli & Bismarck Modeli & Özel Sigorta \\
\hline Örnek & $\begin{array}{l}\text { Ulusal Sağlık } \\
\text { Hizmeti( İngiltere) }\end{array}$ & $\begin{array}{l}\text { Sosyal Sağlı } \\
\text { Sigortası (Almanya) }\end{array}$ & Birleşik Amerika \\
\hline Karar Verme Mekanizması & $\begin{array}{l}\text { Devlet tarafindan } \\
\text { karar verme ve } \\
\text { yönetim }\end{array}$ & $\begin{array}{l}\text { Sigorta fonu ve } \\
\text { hekim birlikleri } \\
\text { tarafından karar } \\
\text { verme ve yönetim }\end{array}$ & $\begin{array}{l}\text { Özel girişimcilik } \\
\text { ilkeleri }\end{array}$ \\
\hline Kaynaklar & Vergiler & $\begin{array}{l}\text { Çalışanların ve } \\
\text { İsveren katkıları ile }\end{array}$ & Özel finansman \\
\hline Sağlık Hizmet Sunucuları & Kamu & Kamu/Özel & Özel \\
\hline
\end{tabular}

Kaynak: Wild ve Gibis, 2003.

Tablo 2'de, sağlık sistem modellerinin karar verme mekanizması, kaynaklar ve sağllk hizmet sunucularına göre Beveridge Modeli, Bismarck Modeli ve Özel Sigorta kapsamında değerlendirilerek ülkelerin uyguladıkları sağlik sistem modelleri gösterilmiştir (Wild ve Gibis, 2003: 189). Türkiye'de sağlık hizmetlerinin finansman yapısı; \%52 oranında prim, \%25,1 oranında vergi, $\% 17,1$ oranında cepten harcamalar, $\% 4,9$ oranında diğer özel harcamalar ve \%0,9 oranında yerel yönetimlerden oluşmaktadır (Atasever, 2018: 14). Türkiye'de genel olarak sağlık hizmetlerinin finansal yapısı ile sınıflandırmada fonda toplanan gelirlere göre genel sağlı sigortası kapsamında Sosyal Güvenlik Kurumu tarafindan alınan primler ile Bismarck modeli; fonda toplanan vergilerle Beveridge modeli ve cepten yapılan harcamalarla Özel Sağlık Sigortası modellerinin uygulandığı görülmektedir.

Sağlık hizmetlerinin finansmanı Sosyal Güvenlik Kurumu başta olmak üzere merkezi yönetim bütçesi, özel sağlık sigorta kuruluşları ve cepten sağlanan kaynaklardan yapılmaktadır. Sosyal Güvenlik Kurumu kamu ve özel sağl1k hizmet sunucularından sağlık hizmetlerini önceden imzalanan sözleşmeler/protokol ile satın almaktadır. Bu yönüyle SGK sağlık politikalarını etkileme gücünde olması ve temel sağlık hizmet alıcısı (monopsonik) gücüne sahip olmasından dolayı önemli bir yere sahiptir (Yurdadoğ, 2007: 81-86).

Sağlık ekonomisinde sağlık hizmetlerinin sunumu, sunulan sağlik hizmetinin finansmanı, yaşam süresinin uzamasına bağlı olarak sağlık problemlerinin artması, ortaya çıkan hastalıkların öngörülememesi, sağl1k alanında teknolojik gelişmeler gibi faktörler ile sağlık hizmetlerin talep ve arz yapıs1, diğer mal ve hizmetlere göre farklılık göstermektedir.

İktisadi büyümenin temel amacı bireylere daha sağlıklı ve kaliteli bir yaşam sağlamaktır. Bu nedenle gelişmekte olan ülkeler bu amaçla, sürekli artan sağlık harcamalarından dolayı sağlık reformları uygulayarak sağlık politikaları belirlemektedir (Tüylüoğlu ve Tekin, 2009). Türkiye'de sağlık sistemi 2003 yılında başlayan 'Sağlıkta Dönüşüm' programıyla yeniden yapılandırılmış ve 2008 yılında Sosyal Güvenlik Reformu ile sağlık harcamalarında ciddi artışlar yaşanmıştır. Genel Sağlık Sigortası sistemine 2012 yılında tüm vatandaşların dahil olması zorunluluğu ile yüksek sağlık harcamalarına karşı düşük gelir seviyesi için mali koruma sağlanmıştır (Daştan ve Çetinkaya, 2015: 109). 
Türkiye'de toplam sağlık harcaması (cari sağlık harcaması ve yatırım harcamas1) 2018-2019 TÜIKK istatistikleri genel devlet ve özel sektöre göre Tablo 3'te sunulmaktadir.

Tablo 3: Genel Devlet ve Özel Sektöre Göre Toplam Sağlık Harcaması 2018, 2019.

\begin{tabular}{lllll}
\hline & & & & (Milyon TL) \\
\hline $\begin{array}{l}\text { Toplam Sağlık } \\
\text { Harcaması }\end{array}$ & 2018 & Pay (\%) & 2019 & Pay $(\%)$ \\
Genel Devlet & $\mathbf{1 6 5 2 3 4}$ & $\mathbf{1 0 0}$ & $\mathbf{2 0 1 ~ \mathbf { 3 1 }}$ & $\mathbf{1 0 0}$ \\
$\quad 128021$ & 77,5 & 159819 & 78 \\
Merkezi Devlet & 40461 & 24,5 & 51492 & 25,6 \\
Mahalli İdareler & 1439 & 0,9 & 1373 & 0,7 \\
Sosyal Güvenlik Kurumu & 86121 & 52,1 & 103954 & 51,7 \\
Özel Sektör & 37213 & 22,5 & 44212 & 22 \\
$\quad$ Hanehalkları & 28665 & 17,3 & 33626 & 16,7 \\
Sigorta Şirketleri & 4625 & 2,8 & 5801 & 2,9 \\
Diğer & 3933 & 2,4 & 4785 & 2,4 \\
\hline
\end{tabular}

Kaynak: TÜİK, https://data.tuik.gov.tr/Saglik-Harcamalari-Istatistikleri-2019.

Tablo 3'te 2018, 2019 yıllarına ait genel devlet ve özel sektör olarak toplam sağlık harcaması yer almaktadır. TÜIK istatistiklerine göre, 2019 yılında toplam sağlık harcamasının, $\% 78$ oran ile genel devlet olduğu ve genel devlet oranı içinde \%51,7'lik en yüksek pay ile Sosyal Güvenlik Kurumu (SGK) olduğu görülmektedir.

Genel sağlık kapsamını sürdürmek ve sağlamak amacıyla Dünya Sağlık Örgütü'ne üye devletler, sağlik finansman sistemini geliştirmeyi hedeflemişlerdir. Bu hedefler arasında kaynakların en iyi şekilde kullanılması, hastalıkları sağlığın mali sonuçlarından koruyan sağlık için yeterli fonların artırılması ve sağlık sigortasının hakkaniyete uygun olması yer almaktadır (Şaşmaz vd., 2019: 853). Sağlık hizmetinin finansmanı sağlık politikası ve sağlık ekonomisi yazınında, önemli kriterlerle değerlendirilmektedir. $\mathrm{Bu}$ kriterler; sağlık hizmetlerine erişim, tüm nüfusa sağlık güvencesi sağlamak, sağlık finansmanının sürdürülebilirliği, sağlık hizmetleri finansmanında verimlilik, sağlık hizmetleri finansmanında adalet ve gelirin yeniden dağıtılması kriterleridir (Yenimahalleli Yaşar, 2010: 32).

Ülkelerin ekonomisindeki gelişmeler sonucunda teknoloji ve tıp alanlarındaki gelişmelere bağlı olarak bireylerin sağlık hizmetlerine olan taleplerinin artması ile sağlık harcamalarında artış gözlenmektedir (Daştan ve Çetinkaya, 2015: 105). Sağlık hizmetlerinin talebi sağlık sigortası kapsamında olanlar ve olmayanlar üzerinden yapılırken, sağlık hizmetlerinin arzı kamu ve özel sektörde faaliyet gösteren değişik kurum ve kuruluşlar tarafından yapılmaktadır (Yurdadoğ, 2007: 592). Ekonomi ve sağlık arasındaki ilişkinin en önemli bölümü toplumsal sağlık düzeyinde yaşanan gelişmelerin dolaylı veya doğrudan toplumsal refah üzerine etkisinin bulunmasıdır. Son zamanlarda yaşanan iki gelişme sağlık ekonomisine ilişkin ilginin arttığı yönündedir. İlk olarak, dünya genelinde ölümlere neden olan bulaşıcı hastalıkların önlenmesine 
yönelik iyileştirici ürünlerin geliştirilmesi ikincisi ise doğumda beklenen yaşam süresindeki artış olarak gözlenmektedir (Çoban, 2009: 2-4). Doğumda beklenen yaşam süresi mevcut ölüm oranlarının değişmediği durumda yenidoğanın ortalama olarak ne kadar süre yaşayacağını gösteren bir sağlık göstergesidir. Kaliteli sağlık hizmetlerine erişim, yükselen yaşam standartları, daha iyi yaşam tarzı gibi faktörler doğumda beklenen yaşam süresi kazanımlara etki ettiği görülmektedir (https://data.oecd.org/healthstat).

Doğuşta yaşam beklentisi, ülkeler arasında sıklıkla sağlık düzeylerinin karşılaştırılmasında kullanılan, ülkelerin gelişmişlik düzeyinin belirlenmesinde önemli yeri olan sağlık göstergelerinden biridir. Ayrıca toplumun sağlık statüsü ve refah düzeyinin belirlenmesinde doğuşta yaşam beklentisi en önemli sağlık göstergelerindendir (Tıraş ve Özbek, 2020: 2896). İktisadi büyüme oranındaki artış beraberinde tüketim harcamalarının, sağlık yatırımlarının ve gelir seviyesinin artmasına neden olmaktadır. Sağlık harcamalarındaki artışın, kaliteli sağlık hizmet sunumunun yaygınlaşmasına bağlı olarak ortalama yaşam süresini artırdığ1 ve bunun sonucunda iktisadi büyümeyi pozitif yönde etkilediği görülmektedir (Erdoğan ve Bozkurt, 2008: 25). Literatür incelemelerinde sağlık harcamalarının nedeni olarak görülen sağlık göstergelerinden doğumda beklenen yaşam süresi ile sağlık harcamaları arasındaki ilişki analiz edilmekte ve çıkan sonuçlar doğrultusunda öngörü yapılmaktadır. Ekonomik Kalkınma ve İşbirliği Örgütü (OECD) verilerine göre ülkelerarası karşılaştırmada kullanılan sağlık göstergelerinden doğumda beklenen yaşam süresinde artış yaşandığı bu nedenle artan sağlık harcamalarının ekonomik büyümeye olan ilişkisi son yıllarda siklıkla incelenmektedir.

Ülkelerin en önemli refah seviyesi olarak kabul edilen ekonomik büyüme, ulusal ekonominin makroekonomik değişkenlere ait göstergelerde meydana gelen iyileşmeler sayesinde gelişim göstererek üretim artışları sayesinde elde edilen gelirlerdeki artışlara ve üretim hacminin genişlemesine bağlı olarak refah seviyesinin yükselmesi olarak tanımlanır (Konak, 2020: 60). Beşeri bir yatırım olan sağlı harcamaları bireylerin gelişimi ve refahı açısından önem arz etmektedir. Sağlık harcamalarının beşeri bir yatırım olması, sağliklı nesillerin gelişimine pozitif etki ederek ülkelerin kalkınma sürecine destek olmaktadır (Şaşmaz vd., 2019: 852). Sağlık harcamalarının ülke ekonomisinde ekonomik büyümeyi artırmada önemli bir gücü olduğu ve sağlı̆̆ın ekonomik büyüme ve ilerleme üzerinde önemli bir etkiye sahip olduğu yapılan çalışmalarla ortaya çıkmaktadır(Özkan ve Zengin, 2018: 4). Beşeri sermayenin yani bireyin bilgi, eğitim düzeyi, sağlık ve yeteneklerini ifade eden kavramların içsel büyüme teorisyenlerine göre uzun dönemde ekonomik büyümede ana unsuru oluşturmaktadır. Bireye yapılan beşeri sermayenin gelişimine olan yatırımlar bireyin üretkenliğini artırarak, iktisadi büyümeye katkı sağladığ görülmektedir (Hayaloğlu ve Bal, 2015: 35).Toplumun ekonomik gelişmişlik ve sağlık düzeyi arasında yakın bir ilişki söz konusudur. Ekonomik gelişimi belli bir düzeyde olan toplumlarda sağlığa ayrılan bütçede artmaktadır. Sağlık düzeyinde iyileşmeler, bireyin sağlıkla ilgili bilgi ve farkındalığının artması ile ekonomik gelişimin hızlandığı görülmektedir (Sayılı vd., 2017: 2).

Cari sağlık harcamalarında, sağlik hizmet sunumuna göre hastanelerin, diğer sağlı hizmet sunucularına göre en fazla paya sahip olduğu, hizmet sunumuna göre bireyin sağlık sunucularından aldığ 1 hizmet sunumunun karşılığ 
olarak finansman yapısına göre Türkiye'de kullanılan sağlık sistem modeli hakkında genel bilgi giriş bölümde ele alınmıştır.

Sağlık hizmetlerinin finansman yapısına göre sinıflandırılmasında sağlık harcamalarının en yüksek oranla Sosyal Güvenlik Kurumu tarafından finanse edildiği için SGK'nın öneminden bahsedilmiştir. Bu amaçla, Türkiye'de 1980-2018 yılları arasında sağlık harcamalarındaki artışı en önemli nedeni olarak görülen ve sıklıkla kullanılan sağlık göstergelerinden doğumda beklenen yaşam süresi ve ekonomik büyüme değişkenleri ile cari sağlık harcamasının gayri safi yurtiçi hasılaya oranı arasındaki ilişki giriş kısmında ele alınarak genel bilgi verilmiştir. İkinci adım olarak literatür araştırmasında daha önce yapılan çalışmalar hakkında bilgi verilmiştir. Sonraki adım olarak veri seti ve yöntem kısmında değişkenlere ait verilerin kaynakları, ADRL modelinde kullanılan denklemler ile ilgili bilgilendirme yapılarak analiz ve bulgular kısmına geçilmiştir. $\mathrm{Bu}$ aşamada, verilerin ekonometrik yöntemle analizi hakkında genel bilgi verilmiştir. Sonraki süreçte, analiz sonrasında elde edilen bulgular doğrultusunda sonuç kısmında genel bir değerlendirme yapılmıştır.

\section{Literatür Taraması}

Ülkelerde sağlık alanında yapılan harcamaların ekonomik büyüme üzerine etkisi literatürde sıkça araştırma konusu olmuştur. Bu konu bağlamında yapılan çalışmalarda ekonomik büyüme ile sağlık harcamaları arasındaki ilişki analiz edilmiş ve çıkan bulgular genelde sağlı harcamalarının ekonomik büyümeye etkisinin olumlu yönde olduğu ve nedensellik analizi sonuçları aralarındaki ilişkinin pozitif yönde olduğunu kanıtlar niteliktedir. Yapılan analiz kapsamında sağlık harcamalarının genel olarak kamu sağlık harcaması, özel sağlık harcaması, kişi başı sağlık harcaması ve toplam sağlık harcamasının gayri safi yurtiçi oranları ile incelendiği görülmektedir. Sağlık göstergelerinden doğumda beklenen yaşam süresi ve sağlık harcamaları ile yapılan analiz sonuçları, aralarında pozitif ilişki olduğu yönündedir. Sağlık harcamaları, ekonomik büyüme ve sağllk göstergelerinin analizi sağlik ekonomi literatüründe önemli bir yere sahiptir. Doğumda yaşam süresine ait verilerin son zamanda ülkelerarası karşılaştırmada yer aldığı görülmektedir. Bunun nedeni olarak doğumda beklenen yaşan süresinin, sağlık harcamalarını önemli ölçüde arttırdığg düşünülmektedir.

Heshmati'ye göre, OECD ülkelerinde 1970-1992 yı1ları arasında GSYİH ile kişi başına düşen sağlık harcamalarını Solow modeline göre incelemiştir. Elde edilen bulgular, sağlık harcamalarının GSYİH etkisinin pozitif olduğunu kantlar niteliktedir (Heshmati, 2001: 12-13). Dreger ve Reimers'e göre, 1975-2001 tarihleri arasında 21 OECD ülkesinin gayri safi yurtiçi hasıla (GSYIH) ile ekonomik büyüme değişkenleri arasındaki ilişki Panel eşbütünleşme analizi ile incelemeleri sonucunda çalışmada sağlık harcamaları ile gayri safi yurtiçi hasıla (GSYIHH) arasında uzun dönemli bir ilişki olduğu sonucuna varıldığı görülmektedir (Dreger ve Reimers, 2005: 1314).

Taban'a göre, Türkiye'de 1968-2003 yılları arasında sağl1k kurumlarının yatak sayıları, doğumda yaşam beklentisi, sağlık kurumlarının sayısı ve sağlık personeli başına düşen kişi sayılarına ait veriler ile reel gayri safi yurtiçi hasıla ile arasındaki ilişkinin Nedensellik testi ile analizi sonrasında çalışmada ampirik bulgulara göre; doğuşta yaşam beklentisi, sağlık personeli 
başına düşen kişi sayısı, sağlık kurumlarının yatak sayısı ile reel gayri safi yurtiçi hasıla arasında çift yönlü nedensellik ilişkisi olduğu sonucuna ulaşıldığı görülmektedir (Taban, 2006: 31). Koyin ve Yung-Hsiang'göre, 1980- 1998 zaman aralığında 15 OECD ülkesinde ekonomik büyüme ve sağlık harcaması verilerini analiz etmişlerdir. Çalışmada elde edilen bulgulara göre, sağlık harcamalarındaki artışın gelir düzeyi ile ilgili olduğunu tespit ettikleri görülmüştür (Koyin ve Yung-Hsiang, 2006: 1).

Erdoğan ve Bozkurt'a göre, Türkiye'de 1980-2005 y1llarında ekonomik büyüme ile yaşam beklentisi verilerini ARDL analizi ile inceleyerek elde edilen bulgular sonucunda, yaşam beklentisi ile iktisadi büyüme arasında pozitif yönlü bir ilişki olduğu sonucuna ulaşıldığı görülmektedir (Erdoğan ve Bozkurt, 2008: 25). Yumuşak ve Yıldırım'a göre, 1980-2005 yılları arasında Türkiye'de doğuşta yaşam beklentisi, sağlık harcamaları ve Gayri Safi Milli Hasıla değişkenlerini çalışmalarında kullanarak Johansen (1988) eşbütünleşme testi ile analizi sonucunda, Türkiye'de sağlık harcamalarından GSMH'ya doğru nedensellik ilişkisinin (negatif ve küçük) olduğunu ayrıca doğuşta yaşam beklentisinden hasılaya doğru nedenselliğin olduğu yönünde tespitleri olmuştur (Yumuşak ve Yıldırım, 2009: 57). Çetin ve Ecevit'e göre, 1990-2006 dönemlerine ait 15 OECD ülkesi için sağlığın, ekonomik büyümeye etkisini Panel veri analizi ile incelemişlerdir. Çalışmalarında bağımsız değişken olarak diğer açıklayıcı değişkenlerin yanında kamu sağlık harcamalarının toplam sağlık harcamalarındaki oranı kullanılmıştır. Panel OLS analiz sonucunda, sağlık harcamaları ile ekonomik büyüme arasında istatiksel olarak anlamlı bir ilişki tespit edemedikleri görülmüştür (Çetin ve Ecevit, 2010: 166).

Teker, Teker ve Sönmez'e göre, Türkiye'de 1975-2009 yıllarında kadın ve erkeklerin yaşam süreleri bağımlı değişken olarak doktor sayıları, sağlık harcamalarının milli gelire oranı, yaşlı nüfusun çalışabilir nüfusa oranı, yatak sayısı hasta sayıları verileri bağımsız değişken olarak alınıp Eşbütünleşme testi ile incelemeleri sonucunda, çalışmada her bir bağımsız değişkenin kadın ve erkeklerin yaşam sürelerine olan etkisinin istatistiksel olarak anlamlı olduğu sonucuna ulaşıldığı görülmektedir (Teker, Teker ve Sönmez, 2012: 118). Akar'a göre, Türkiye'de Ocak 2004-Mart 2013 periyodunda ekonomik büyüme, sağlık harcamaları ve sağlık harcamaların nispi fiyatı verileri Eşbütünleşme analizi ve hata düzeltme modeline göre incelenmesi sonucunda, uzun dönemde sağl1k harcamalarının nispi fiyatı, sağlık harcamaları ve ekonomik büyüme arasında eşbütünleşme olduğu ama kısa dönemde anlamlı bir ilişki olmadığ 1 sonucuna ulaşıldığı görülmektedir (Akar,2014: 311).

Jaba, Balan ve Robu'ya göre, 1995-2010 yılları arasında gelir düzeyi ve coğrafi konumlarına göre gruplandırılmış 175 ülkenin sağlık harcamaları ile ortalama yaşam süresi değişkenlerini Panel veri analizi incelenmesi sonucunda, sağlık harcamaları ile ortalama yaşam süresi arasında istatiksel olarak anlamlı bir ilişkinin olduğu görülmektedir (Jaba, Balan ve Robu, 2014: 108). Monsef ve Mehrjardi'ye göre, 2002-2010 döneminde 136 ülke için yaşam beklentisini ve yaşam beklentisini etkileyen sosyal, ekonomik ve çevresel faktörler ele alınarak Panel veri yöntemi ile yapılan analiz sonucunda elde edilen bulgular, temel ekonomik faktörler olarak gösterilen enflansyon ve işsizliğin yaşam süresini olumsuz etkilediğini, gayri safi milli gelir ve safi sermaye oluşumunun yaşam beklentisi üzerine olumlu etkisi olduğunu ve sosyo-çevresel faktörlerden 
kentselliğin ölümlerin sebebi olduğu sonucuna ulaşıldığı görülmektedir (Monsef ve Mehrjardi, 2015: 1251).

Hayaloğlu ve Bal'a göre, 2000-2013 döneminde 54 üst orta gelirli ülkeler için ekonomik büyüme ile sağlık harcamaları arasındaki ilişkiyi Panel veri analizi ile incelemiş ve çıkan bulgulara göre, çalışmada toplam sağlık harcamalarındaki artışın ekonomik büyümeyi olumlu yönde etkilediği tespit edilmiştir (Hayaloğlu ve Bal, 2015: 35). Istaiteyeh'e göre, çalışmasında 19902014 yıllarını kapsayan sürede Ürdün'de yaşam beklentisi ile açıklayıcı değişkenlerden kişi başı gayri safi yurtiçi hasıla ile işsizlik oranı verilerini VAR analizi ile incelemiş ve elde edilen ampirik bulgulara göre, kişi başı gayri safi yurtiçi hasılanın \%21 oranında yaşam beklentisi üzerine etkisi olduğunu ayrıca \%19 işsizlik oranının, yaşam beklentisine etkisi olduğu sonucuna ulaşıldığı görülmektedir (Istaiteyeh, 2017: 45).

Linden ve Ray'a göre, 1970-2012 yıllarında 34 OECD ülkesinin doğumda beklenen yaşam süresi ile kamu ve özel sağlık harcamalarını Panel Var ve Etki-Tepki analizi ile incelemeler sonucunda çalışmada elde edilen bulgulara göre, sağlık harcamaları ile doğumda beklenen yaşam süresi arasında pozitif ilişki tespit edilmiştir (Linden ve Ray, 2017: 1). Boz ve Aslan'a göre, 1980-2014 yıllarında Türkiye'de kişi başı kamu sağlık harcamaları ile kişi başı gayri safi yurt içi hasıla değişkenlerini kullanarak Toda Yamamoto ve Var Modeli ile analiz sonucunda, kişi başı GSYİH'dan kişi başı kamu sağlık harcamalarına doğru nedensellik tespit edilmediği ancak kişi başı kamu sağlık harcamalarından kişi başı GSYIH'ye doğru tek yönlü nedensellik olduğu sonucuna ulaşıldığ görülmektedir (Boz ve Aslan, 2018: 1).

Güven, Şimşek ve Güven'e göre, 2000-2015 yılları arasında MENA ülkelerinde ekonomik büyüme ve sağllk harcamaları değişkenlerini Panel veri analizi ile incelemeleri sonucunda elde edilen ampirik bulgulara göre, MENA ülkelerinde sağlık harcamalarının ekonomik büyüme üzerinde etkisinin negatif olduğu, doğumda yaşam beklentisi ve bebek ölüm hızının ekonomik büyüme üzerine pozitif bir etkiye sahip olduğu sonucuna ulaşılmıştır (Güven, Şimşek ve Güven, 2018: 34). Kılıç ve Beşer'e göre, 1995-2016 yılları arasında 8 Doğu ve Merkezi Avrupa ülkesi için ekonomik büyüme ile sağlık harcamaları değişkenlerini Panel veri analizi ile çıkan bulgular sonucunda, ekonomik büyümeden sağlık harcamalarına doğru çift yönlü nedensellik olduğu tespit edilmiştir (K1lıç ve Beşer, 2018: 373).

Sever ve İğdeli'ye göre, Türkiye'de 1980-2017 dönemine ait kişi başı gelir düzeyi, kişi başına düşen kamu sağlık harcamaları, kişi başına düşen özel sağlık harcamaları, ortalama beklenen yaşam süresi ile bebek ölüm hızı değişkenlerinin Vektör Hata Düzeltme modeli, Johansen Eşbütünleşme, FMOLS tekniği ile yapılan analiz sonuçlarına göre, çalışmada kişi başı kamu ve kişi başı özel sağlık harcamalarındaki artışların ortalama yaşam beklentisini pozitif yönde etkilediği ayrıca kişisel gelir, kişi başı kamu ve özel sağlık harcamalarındaki artışların bebek ölüm hızını düşürdüğü tespit edilmiştir (Sever ve İğdeli, 2019: 246). Şaşmaz, Odabaş ve Yayla'ya göre, 2000-2015 yılları arasında 34 OECD ülkesinde sağlı harcamaları ve kalkınma (İnsani Gelişmişlik Endeksi) değişkenlerini ile Panel veri analizi ile incelemeleri sonucunda çalışmada, sağlık harcamaları ile kalkınma arasında uzun dönemli bir ilişki olduğu ve sağlık harcamalarının kalkınma üzerinde pozitif etkisi olduğu sonucuna ulaşılmıştır (Şaşmaz, Odabaş ve Yayla, 2019: 851). 
Aydın'a göre, 2000-2016 yılları arasında OECD ülkeleri arasında beklenen yaşam süresi, işsizlik ve kişi başı GSYİH değişkenleri ile Panel Regresyon analizi ve Granger Nedensellik analizi sonrası çıkan bulgulara göre, beklenen yaşam süresi ile kişi başı GSYIHH arasında çift yönlü nedensellik, sağlık harcamalarından beklenen yaşam süresine göre tek yönlü nedensellik ilişkisinin olduğu tespit edilmiştir. Çalışmada değişkenlerin Panel Regresyon analiz sonucuna göre, OECD ülkelerinde beklenen yaşam süresini etkileyen en önemli faktörün sağlık harcamaları olduğu sonucuna ulaşıldı̆̆ 1 görülmektedir (Aydın, 2020: 163). Boz, Taş ve Önder'e göre, 2005 ve 2015 yılarında 35 OECD ülkesinde bağımlı değişken olarak satın alma gücü paritesine göre hesaplanmış kişi başına düşen sağlık harcaması ile kentleşme, yaşlanma ve gelir bağımsız değişkenlerinin Panel Regresyon modeli ile analizi sonucunda çıkan ampirik bulgulara göre; yaşlanma, kentleşme ve gelirin sağllk harcamalarının artmasında etkili olduğu tespit edilmiştir (Boz, Taş ve Önder, 2020: 2).

Çelik'e göre, 2000-2016 yıllarında G20 Ülkelerinde kişi başına düşen sağlık harcamaları ile ekonomik büyüme verilerini Dumitrescu-Hurlin (2012) Panel Nedensellik testi ile analiz etmiştir. Çalışmada elde edilen bulgular sonucunda ekonomik büyümeden sağlık harcamalarına doğru tek yönlü nedensellik ilişkisinin olduğu, uzun dönemli katsayı sonuçlarına göre kişi başına düşen sağlık harcamalarındaki \%1'lik artışın, ekonomik büyüme rakamlarını \%0,81 oranında artırdığı sonucuna ulaşıldığı görülmektedir (Çelik, 2020: 1).

Çeştepe, Yıldırım ve Yıldız'a göre, Türkiye'de 2007-2017 yıllarına ait bebek ölüm hızı, kamu yatırımları, hastane yatak sayısı, lisans mezunu ve lise mezunu kişi sayısı ithalat ve ihracat bağımsız değişkenlerini Sistem GMM analizi ile gayri safi yurt içi hasılaya olan etkisinin analizi sonucunda, bebek ölüm hızında \%1'lik azalma gayri safi yurtiçi hasılada \%0,03'lük artışa neden olduğunu ayrıca yatak sayısındaki \%1'lik artış gayri safi yurt içi hasılada $\% 0,16$ 'lık bir artışa neden olduğu tespit edildiği görülmektedir (Çeştepe, Yildırım ve Yildiz, 2020: 175).

Tıraş ve Özbek'e göre, 1980-2018 yılları arasında 28 OECD ülkesinde kişi başı karbondioksit emisyonu, kaba doğum oranı, kentleşme oranı ile kişi başı gayri safi yurtiçi hasıla bağımsız değişkenlerinin doğuşta yaşam beklentisine etkisi Dinamik Panel analizi sonucunda, kaba doğum oranı ile karbondioksit emisyonunun istatiksel olarak anlamsız olduğu, kişi başı gelirin ve kentleşmenin doğuşta yaşam beklentisi üzerine etkisinin istatiksel olarak anlamlı olduğu sonucuna ulaşıldığı görülmektedir. Çalışmada elde edilen bulgular kentleşmede meydana gelen \%1'lik artışın, doğuşta yaşam beklentisini yaklaşık \%0,27 oranında artırdı ğı, kişi başı gelirde \%1'lik artışın doğuşta yaşam beklentisini yaklaşık \%0,007 oranında azalttığı tespit edilmiştir (Tıraş ve Özbek, 2020: 2893).

Literatür araştırmalarında genel olarak bakıldığında doğumda beklenen yaşam süresine etki eden farklı değişkenlerin olduğu ve son y1llarda güncel verilere göre yapılan nedensellik analiz sonuçları, doğumda beklenen yaşam süresi ile ekonomik büyüme arasında pozitif ilişkinin olduğunu kanıtlar niteliktedir. Genel olarak yapılan araştırmalarda, doğumda beklenen yaşam süresini etkileyen en önemli unsurun sağlık harcamaları olduğu sonucuna varıldığı görülmektedir. 


\section{Veri Seti ve Yöntem}

Çalışmada, Türkiye'de 1980-2018 yılları arasında doğumda beklenen yaşam süresi, ekonomik büyüme ve cari sağlık harcamasının GSYİH'ya ait veriler incelenmiştir. Doğumda beklenen toplam (kadın ve erkek) yaşam süresi verileri, Dünya Kalkınma Bankası (World Bank) veri tabanından logaritması alınarak kullanılmıştır. Cari sağlık harcamasının GSYİH'ya ilişkin veriler, OECD veri tabanından yüzde olarak alınmıştır. Bağımsız değişken olarak ekonomik büyüme oranı, Dünya Kalkınma Bankası veri tabanından yüzde olarak alınmıştır. Analizde kullanılan değişkenler hakkında genel bilgiler Tablo 4'te gösterilmektedir.

Tablo 4: Analizde Kullanılan Değișkenler.

\begin{tabular}{|c|c|c|c|}
\hline Değişkenin Adı & $\begin{array}{l}\text { Çalışmadaki } \\
\text { Kisa Adı }\end{array}$ & Dönemi & Kaynağ1 \\
\hline $\begin{array}{l}\text { Cari Sağlık Harcamasının } \\
\text { Gayri Safi Yurtiçi Hasılaya Oranı } \\
(\%)\end{array}$ & $\mathrm{CSH}$ & $\begin{array}{l}1980- \\
2018\end{array}$ & $\begin{array}{l}\text { https://data.oecd.org/healthres/health- } \\
\text { spending. }\end{array}$ \\
\hline Ekonomik Büyüme (\%) & GSYİH & & \\
\hline $\begin{array}{l}\text { Doğumda Beklenen Yaşam Süresi } \\
\text { Toplam }(\mathrm{y} 1)^{*}\end{array}$ & DBYS & $\begin{array}{l}1980- \\
2018\end{array}$ & $\begin{array}{l}\text { https://data.worldbank.org/country/ } \\
\text { https://data.worldbank.org/indicator }\end{array}$ \\
\hline
\end{tabular}

Şekil 3'te, doğumda beklenen yaşam süresi toplam (kadın ve erkek) değişkeni ile ekonomik büyüme ve cari sağlık harcamasının gayri safi yurtiçi hasılaya oranlarının zaman serisi grafikleri gösterilmektedir.
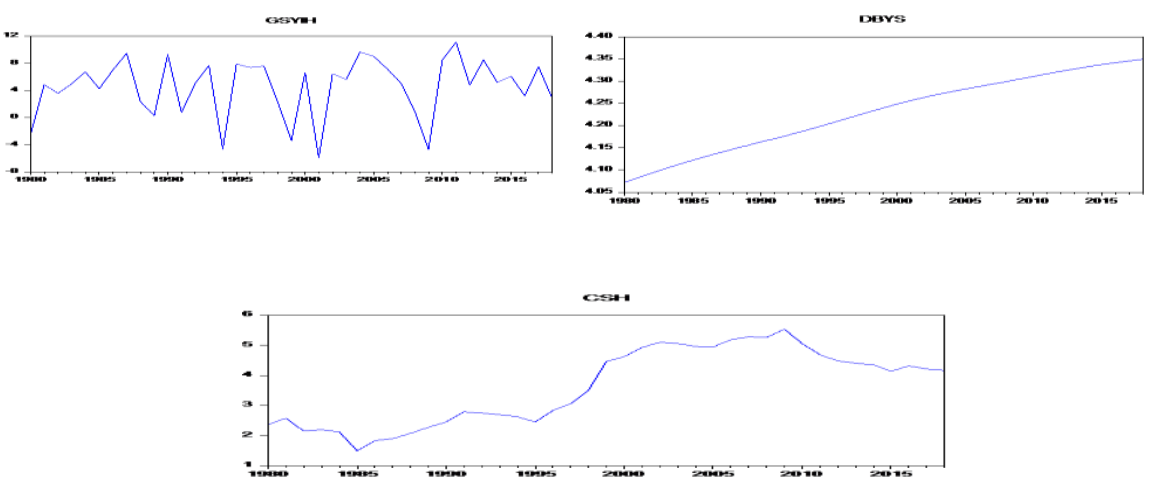

Şekil 3: Modeldeki Değişkenlerin 1980-2018 Dönemi Grafikleri

Yöntem olarak çalışmada, ARDL sınır testi yaklaşımı, Pesaran vd. (2001) geliştirdikleri ARDL sınır testi ile değişkenlerin analizi yapılmıştır. Bağımlı ve bağımsız değişkenler arasındaki uzun dönem dönemli ilişkiyi tespit etmek için Engle ve Granger (1987) ve Johansen (1988) geliştirdikleri eşbütünleşme testlerinin sadece değişkenlerin seviye değerinde yani $\mathrm{I}(0)^{\prime}$ da durağan olmaları halinde kullanıldığ literatür incelemelerinde görülmektedir (Polat ve Gemici, 2017: 397). ARDL modeli ile sinır testinde incelenen değişkenlerin seviye değeri $\mathrm{I}(0)$ veya birinci farkına $\mathrm{I}(1)$ bakılmadan uygulanabilmesi ile eşbütünleşme testi yapmak mümkün hale gelmiştir (Uçan 
ve Atay, 2016: 218). ARDL sınır testinin en önemli bir diğer artıs1, klasik eşbütünleşme testleri ile karşılaştırıldığında kısıtsız hata düzeltme modeli ile seriler arasındaki kısa ve uzun dönem dinamikleri hakkında güvenilir ve doğru sonuçlar verebilmesidir (Akel ve Gazel, 2014: 30-31). ARDL sınır testi küçük örneklemlerde diğer eşbütünleşme testleri ile kıyaslandığında daha iyi sonuçlar verdiği görülmektedir (Polat ve Gemici, 2017: 397).

Eşitlik 1'de, değişkenler için doğrusal tahmin denklemi oluşturulur.

$$
C S H_{t}=\beta_{0}+\beta_{1} G S Y \dot{I} H_{t}+\beta_{2} D B Y S_{t}+\varepsilon_{t}
$$

Denklem 1'de ki eșitlikte, ilk adım olarak değișkenler arasında uzun dönemli bir ilişkinin olup olmadığı test edilir. Değiş̧kenler arasında uzun dönem ilişki tespit edilmesinden sonra ikinci adım, değişkenler arasında uzun dönem katsayı tahmini belirlemektir. Son adım kısa vadeli esneklikleri tahmin etmektir (Narayan ve Smyth, 2006: 337).

Denklem 2'de, $\Delta$ açıklayıcı ve açıklanan değişkenlerin gecikmelerin farkını ve $\varepsilon_{\mathrm{t}}$ ise hata terimini ifade eder. ARDL modelinde bağımlı ve bağımsız değişkenlere ait y1llık zaman serilerinde modele uygun kritere göre belirlenmiş gecikme sayıları $\mathrm{p}, \mathrm{r}$, t olarak gösterilir.

$$
\begin{gathered}
\Delta C S H_{t}=\beta_{0}+\sum_{i=1}^{p} \beta_{1 i} \Delta C S H_{t-i}+\sum_{i=0}^{r} \beta_{2 i} \Delta G S Y \dot{\mathrm{I}} H_{t-i}+\sum_{i=0}^{t} \beta_{3 i} \Delta D B Y S_{t-i}+ \\
\alpha_{1} C S H_{t-1}+\alpha_{2} G S Y \dot{I} H_{t-1}+\alpha_{3} D B Y S_{t-1}+\varepsilon_{t} \\
\mathrm{H}_{0}=\alpha_{1}=\alpha_{2}=\alpha_{3}=0 \text { (Eşbütünleşme Yoktur) } \\
\mathrm{H}_{1} \neq \alpha_{1} \neq \alpha_{2} \neq \alpha_{3} \neq 0 \text { (Eşbütünleşme Vardır) }
\end{gathered}
$$

Değişken arasında eşbütünleşme ilişkisini ifade eden $\mathrm{H}_{1}$ hipotezi ile değişkenler arasında eşbütünleşme olmadığı anlamına gelen $\mathrm{H}_{0}$ hipotezi karşılaştırılır. Değişkenler arasında uzun dönemli bir ilişkide $\mathrm{H}_{0}$ (Eşbütünleşme Yoktur) hipotezi reddedilerek, sinır testi ile uzun dönem katsayıları belirlenmektedir.

Denklem 3'te, ARDL analizi ile değişkenlerin uzun dönem katsayı sonuçları ile bağımsız değişkenlerin bağımlı değişkene olan etkisi sayısal olarak ifade edilir. ARDL sınır testi ile hesaplanan F istatistiği, alt ve üst değerlerle karşılaştırılarak elde edilen sonuçlara göre uzun dönem katsayıları belirlenir.

Pesaran vd. (2001) alt değer ve üst değerlerden oluşan farklı anlam düzeyleri için kritik değerler seti türetmişlerdir. Bağımlı ve bağımsız değiş̧kenlere ait gözlem sayısının küçük olması durumunda hesaplanan kritik değerler Pesaran vd. (2001) tarafindan rapor edilen kritik değerlerden önemli ölçüde sapma olduğu gözlemlenmiştir. Bu nedenle Narayan (2005) tarafindan sınır testi için türetilen 30-80 gözlem sayısında daha güvenilir sonuçlar veren üst ve alt kritik değerler kullanılmıştır (Uzgören ve Akalin, 2016: 70).

$$
\begin{gathered}
\mathrm{CSH}_{\mathrm{t}}=\beta_{0}+\sum_{\mathrm{i}=1}^{\mathrm{p}} \beta_{1 \mathrm{i}} \mathrm{CSH}_{\mathrm{t}-\mathrm{i}}+\sum_{\mathrm{i}=0}^{\mathrm{r}} \beta_{2 \mathrm{i}} \mathrm{GSYIHH}_{\mathrm{t}-\mathrm{i}}+ \\
\sum_{\mathrm{i}=0}^{\mathrm{t}} \beta_{3 \mathrm{i}} \text { DBYS }_{\mathrm{t}-\mathrm{i}}+\mathrm{EC}_{\mathrm{t}}
\end{gathered}
$$

ARDL sinır testinde uzun dönem katsayıların belirlenmesinde hesaplanan $\mathrm{F}$ istatistiği değeri, $\mathrm{I}(0)$ alt değer ve $\mathrm{I}(1)$ üst değerleri ile karşılaştırılarak $\mathrm{H}_{0}$ hipotezinin $\mathrm{H}_{1}$ hipotezine karşı sınanması ile test edilir. Hesaplanan $\mathrm{F}$ istatistiği değeri, $\mathrm{I}(0)$ olarak gösterilen alt değerden küçükse $\mathrm{H}_{0}$ hipotezi reddedilemeyerek değişkenler arasında eşbütünleşmenin olmadığı sonucuna varılmaktadır. Diğer bir olasılık, hesaplanan F istatistiğinin I(1) üst değerden büyük olması durumunda $\mathrm{H}_{0}$ hipotezi reddederek aralarında eşbütünleşme olduğu tespit edilir. Son olarak hesaplanan F istatistiği, karasızlık bölgesi olarak ifade edilen, I(0) alt değer ile I(1) üst değer arasında kalması 
durumunda eşbütünleşmenin olup olmadığı ile ilgili bir yargıya varilamayacaktır.

$$
\mathrm{EC}_{\mathrm{t}}=\mathrm{CSH}_{\mathrm{t}}-\beta_{0}-\beta_{1} \mathrm{GSYIH}_{\mathrm{t}}-\beta_{2} \mathrm{DBYS}_{\mathrm{t}}
$$

Eşitlik 4'te, uzun dönem hata düzeltme terimi $\mathrm{EC}_{\mathrm{t}}$ ile ifade edilir. ARDL sınır testinde hesaplanan $F$ istatistiğinin $I(1)$ üst değerden büyük olduğunda değişkenler arasında uzun dönemli ilişki olduğu tespit edilerek, kısıtsız hata düzeltme modeli ile ARDL sınır testine göre bağımsız değişkenlere ait uzun dönem katsayılar belirlenir. Aralarında uzun dönemli denge ilişkisi bulunan seriler arasında kısa dönemde dengesizlikler yaşanabilir (Yumuşak ve Y1ldırım, 2009: 65). Denklem 5'te ARDL modeline göre en küçük kareler (OLS) yöntemiyle oluşturulan hata düzeltme modelinde hata düzeltme terimine ait katsay1 $(\delta)$ belirlenir.

$$
\begin{aligned}
\Delta \mathrm{CSH}_{\mathrm{t}}= & \beta_{0}+\sum_{\mathrm{i}=1}^{\mathrm{p}} \beta_{1 \mathrm{i}} \Delta \mathrm{CSH}_{\mathrm{t}-\mathrm{i}}+\sum_{\mathrm{i}=0}^{\mathrm{r}} \beta_{2 \mathrm{i}} \Delta \mathrm{GSYIH}_{\mathrm{t}-\mathrm{i}}+ \\
& \sum_{\mathrm{i}=0}^{\mathrm{t}} \beta_{3 \mathrm{i}} \Delta \mathrm{DBYS}_{\mathrm{t}-\mathrm{i}}+\delta \mathrm{ECM}_{\mathrm{t}-1}+\varepsilon_{\mathrm{t}}
\end{aligned}
$$

Eşitlik 5'te ki hata düzeltme modelinde, hata düzeltme terimi olarak ifade edilen $\operatorname{ECM}(\mathrm{t}-1)$ değişkeni ARDL uzun dönem modelinden en küçük kareler yöntemiyle elde edilen kalıntı serisinin bir dönem önceki değerini ifade etmektedir (Uçan ve Atay, 2016: 219). ARDL hata düzeltme modelinde ECM(t$1)$ terimine ait olan $(\delta)$ katsayı değerini hesaplanması ile zaman serilerinde meydana gelen dengesizliklerin ortalama ne kadar sürede uzun dönem denge değerine geleceğini göstermektedir. Modelde hata düzeltme katsayı $(\delta)$ değerinin 0 ile -1 aralığında bir değer alması ve istatiksel olarak anlamlı olması gerekir.

Son olarak Cusum ve CusumsQ istaistikleri ile uzun dönem katsayıları ve kısa dönem dinamikleri incelenerek ARDL modelindeki katsayıların istikrarlı olup olmadığı ve yapısal kırılma ile ilgili grafikler yorumlanmıştır.

\section{Analiz ve Bulgular}

İlk aşamada, bağımlı ve bağımsız değişkenlere birim kök testi uygulayarak modeldeki değişkenlerin durağan olup olmadığına bakılır. Analizi yapılacak olan modeldeki değişkenlerin birim kök içermesi (durağan olmaması) durumunda $\mathrm{t}$ istatistiği sonucu normal dağılmış standart hatalar elde edilemeyeceği için geçerli olmayacaktır (Polat ve Gemici, 2017: 398). Bu nedenle modelde kullanılacak bağımlı ve bağımsız değişkenlerin durağan olması (birim kök içermemesi) gerekir. Değişkenlerdeki durağanlık ifadesi zaman içinde serilerin gecikme seviyesine bağl bir kovaryansa, sabit bir varyansa ve ortalamaya sahip olmasidır (Akel ve Gazel, 2014: 32). Granger ve Newbold (1974), birim kök içeren yani durağan olmayan serilerde sahte regresyon problemi ile karşılaşacağını ifade etmiştir. Sahte regresyon olmaması için zaman serilerinin durağan olması, diğer bir ifadeyle varyansı, kovaryansı ve ortalamalarının zaman içinde değişmemesi gerektiğini ileri sürmüştür (Uzgören ve Akalin, 2016: 71). Analizde kullanılacak değişkenlerin durağanlıkları Augmented Dickey-Fuller (ADF) birim kök testleri ile elde edilen sonuçlar Tablo 5'te sunulmuştur. 
Medeniyet Araştırmaları Dergisi, Cilt: 6 Sayı: 1 Yul: 2021

Journal of Civilization Studies, Volume: 6 Issue: 1 Year: 2021

Tablo 5: ADF (Augmented Dickey-Fuller Birim Kök Test Sonuçları

\begin{tabular}{llll|lll}
\hline & \multicolumn{3}{c}{ Seviye Düzeyi } & \multicolumn{3}{c}{ Birinci Fark } \\
\hline Sabitli & CSH & DBYS & GSYIH & (CSH) & (DBYS) & (GSYIH) \\
Olasılık Değeri & -10.080 & -12.055 & -67.874 & -46.606 & 0.1797 & -106.622 \\
\hline Sabitli ve Trendli & 0.7404 & 0.6598 & $0.0000^{* * *}$ & $0.0006 * * *$ & 0.9670 & $0.0000 * * *$ \\
Olasılık Değeri & -0.6817 & 19.066 & -66.905 & -46.254 & -47.318 & -105.172 \\
\hline Sabitsizve Trendsiz & 0.9673 & 10.000 & $0.0000^{* * *}$ & $0.0036^{* * *}$ & $0.0028 * * *$ & $0.0000^{* * *}$ \\
Olasılık Değeri & 0.2809 & -17.527 & -19.035 & -46.544 & -12.384 & -108.179 \\
\hline \hline
\end{tabular}

Not: ***, \%1*,\%10 önem seviyesini ifade etmektedir.

ADF birim kök testine göre elde edilen istatiksel değerler, $\mathrm{H}_{0}$ (serilerde birim kök var) hipotezi, $\mathrm{H}_{1}$ (serilerde birim kök yok) hipotezine karş1 sınanarak test sonuçlarının, MacKinnon kritik değerleri ile karşılaştırılıp serilerin durağan olup olmadığı test edilir (Konak, 2020: 66). Tablo 5'te ki ADF test sonuçlarına göre, bağımlı değişken olarak cari sağlık harcamasının GSYİH'ya oranı ile bağımsız değişkenlerden doğumda beklenen yaşam süresi ve ekonomik büyüme oranlarının sabitli ve trendli, birinci fark I (1) değerleri MacKinnon kritik değerleri ile karşılaştırılarak \%1 önem seviyesinde " $\mathrm{H}_{0}$ : Seride birim kök var" hipotezi reddedilerek zaman serilerinin durağan olduğu diğer bir ifadeyle birim kök içermediği tespit edilmiştir. Bu aşamadan sonra ARDL modeline uygun kritere göre belirlenmiş bağımlı ve bağımsız değişkenlere ait uygun gecikme sayıları Tablo 6'da sunulmaktadır.

Tablo 6: ARDL $(4,3,3)$ Sonuçları

\begin{tabular}{lcccc}
\hline Değişkenler & Katsayı & Standart Sapma & t-istatistiği & Olasıllk \\
\hline CSH(-1) & 0.885020 & 0.155070 & 5.707 .241 & 0.0000 \\
CSH(-2) & -0.005482 & 0.227921 & -0.024051 & 0.9810 \\
CSH(-3) & 0.568124 & 0.225437 & 2.520 .099 & 0.0195 \\
CSH(-4) & -0.686445 & 0.176385 & -3.891 .733 & 0.0008 \\
GSYIH & -0.006670 & 0.010345 & -0.644714 & 0.5258 \\
GSYIH(-1) & 0.022665 & 0.010600 & 2.138 .259 & 0.0439 \\
GSYIH(-2) & 0.018944 & 0.009737 & 1.945 .523 & 0.0646 \\
GSYIH(-3) & 0.031964 & 0.009606 & 3.327 .288 & 0.0031 \\
DBYS & 8.390 .320 & 3.429 .760 & 2.446 .329 & 0.0229 \\
DBYS(-1) & -2.384 .891 & 9.889 .491 & -2.411 .541 & 0.0247 \\
DBYS(-2) & 2.487 .285 & 1.008 .899 & 2.465 .346 & 0.0220 \\
DBYS(-3) & -9.339 .860 & 3.619 .307 & -2.580 .566 & 0.0171 \\
C & -3.255 .897 & 8.039 .291 & -4.049 .980 & 0.0005 \\
\hline R-squared & 0.983963 & & Durbin-Watson & 1.806 .997 \\
Adjusted R-squared & 0.975215 & & & \\
\hline \hline
\end{tabular}

Tablo 6'da ARDL $(4,3,3)$ modelindeki değişkenlerin uygun gecikme sayıları denklem 2'de belirtilen formülle belirlenmiştir. Bu formüle göre ARDL modelinde zaman serileri yıllık veri olarak alındığı için maksimum gecikme 
uzunluğu Akaike bilgi kriteri (Akaike information criterion-AIC) göre 4 olarak belirlendikten sonra bağımlı ve bağımsız değişkenlerin formüle uygun gecikme sayılarını ifade eden $\mathrm{p}, \mathrm{r}, \mathrm{t}$ ile eşleştirilen ARDL $(4,3,3)$ modeli, Eviews 10 programında belirlenmiştir. Denklem 3'e göre belirlenen ARDL $(4,3,3)$ modelinde bağımlı değişken olarak cari sağlık harcamasının gayri safi yurtiçi hasılaya oranı $(\mathrm{CSH})$ ile açıklayıcı değişkenlerden doğumda beklenen yaşam süresi (DBYS) ve ekonomik büyüme (GSYIH) değişkenlerine ait uygun gecikme sayıları tablo 6'da ARDL $(4,3,3)$ modeli ile belirlenmiştir. Sonraki aşama olarak ARDL $(4,3,3)$ sınır testine göre hesaplanan F istatistiği, alt sınır ve üst sınır değerleri ile önem düzeyine göre Tablo 7'de sunulmaktadır.

Tablo 7: F İstatistiği ile Alt ve Üst Sınır Değerleri

\begin{tabular}{lllllll}
\hline Model & M & K & F İstatistiği & Önem Düzeyi & Alt Sinır & Üst Sınır \\
\hline & & & & $10 \%$ & 2.845 & 3.623 \\
\multirow{2}{*}{ ARDL $(4,3,3)$} & 4 & \multirow{2}{*}{3} & \multirow{2}{*}{6.277 .365} & $5 \%$ & 3.478 & 4.335 \\
& & & & $1 \%$ & 4.948 & 6.028 \\
\hline \hline
\end{tabular}

K değişken sayısını, M maksimum gecikme sayısını ifade eder.

Tablo 7'de denklem 3'te belirtilen formüle göre ARDL $(4,3,3)$ sinır testinde hesaplanan $F$ istatistiği 6.277 değeri ile üst sınır (6.028) değerinden büyük olduğu için \%1 önem seviyesine göre $\mathrm{H}_{0}$ hipotezi reddedilerek değişkenler arasında uzun dönemli bir ilişki olduğu sonucu tespit edilmiştir. ARDL $(4,3,3)$ modeline ait uzun dönem sonuçları Tablo 8'de sunulmaktadır.

Tablo 8: ARDL $(4,3,3)$ Uzun Dönem Sonuçları

\begin{tabular}{|c|c|c|c|c|}
\hline \multicolumn{5}{|c|}{ Uzun Dönem Katsayıları } \\
\hline Değişkenler & Katsayı & Standart Sapma & t-istatistiği & Olasılık \\
\hline DBYS & 3.115 .514 & 6.581 .239 & 4.733 .933 & $0.0001 * * *$ \\
\hline GSYIH & 0.280181 & 0.141424 & 1.981 .148 & $0.0602 *$ \\
\hline $\mathrm{C}$ & -1.363 .538 & 3.041 .220 & -4.483 .524 & $0.0002 * * * *$ \\
\hline
\end{tabular}

$\mathrm{EC}=\mathrm{CSH}-(31.1551 \mathrm{DBYS}+0.2802 \mathrm{GSYIH}-136.3538)$

Tablo 8'de denklem 4'te kısıtsız hata düzeltme modeli ile bağımsız değişkenlere ait uzun dönem katsayıları gösterilmektedir. Değiş̧kenlere ait uzun dönem katsayıları $\mathrm{t}$ istatistiği olasılık değerleri ile önem seviyelerine göre istatistiksel olarak anlamlılığı belirlenmiştir. ARDL $(4,3,3)$ sınır testi uzun dönem katsayılara göre doğumda beklenen yaşam süresindeki \%1'lik artışın, cari sağlık harcamasının gayri safi yurtiçi hasılaya oranını yaklaşı $\% 31,15$ oranda arttırdığ 1 ve bu sonucun \%1 önem seviyesinde istatiksel olarak anlamlı olduğu tespit edilmiştir. Ayrıca ekonomik büyüme oranında \%1'lik artış, cari sağlık harcamasının GSYIH'ya payını yaklaşık \%0.28 oranda artırdığı ve bu sonucun \%10 önem seviyesinde istatiksel olarak anlamlılı̆̆ test edilmiştir.

ARDL $(4,3,3)$ modelinde analiz sonucunda uzun dönem katsayılar belirlendikten sonra kısa dönemde oluşan dengesizliklerin ne kadar süre sonra 
giderileceğini öğrenmek için hata düzeltme modeline göre hesaplanan hata düzeltme katsayı değeri ile ARDL $(4,3,3)$ modeline ait tanımlayıcı testler Tablo 9'da sunulmaktadir.

Tablo 9: ARDL $(4,3,3)$ Hata Düzeltme Modeli

\begin{tabular}{|c|c|c|c|c|}
\hline \multicolumn{5}{|c|}{ Hata Düzeltme Katsayı Sonuçları } \\
\hline Değişkenler & Katsay 1 & Standart Sapma & t-istatistiği & Olasilık \\
\hline$\Delta(\mathrm{CSH}(-1))$ & 0.123803 & 0.129980 & 0.952477 & 0.3512 \\
\hline$\Delta(\mathrm{CSH}(-2))$ & 0.118321 & 0.128728 & 0.919154 & 0.3680 \\
\hline$\Delta(\mathrm{CSH}(-3))$ & 0.686447 & 0.146241 & 4.693 .931 & 0.0001 \\
\hline$\Delta(\mathrm{DBYS})$ & 8.390 .387 & 2.796 .942 & 2.999 .843 & 0.0066 \\
\hline$\Delta(\mathrm{DBYS}(-1))$ & -1.553 .312 & 5.317 .465 & -2.921 .151 & 0.0079 \\
\hline$\Delta(\mathrm{DBYS}(-2))$ & 9.339 .928 & 2.858 .648 & 3.267 .254 & 0.0035 \\
\hline$\Delta(\mathrm{GSYIH})$ & -0.006670 & 0.007214 & -0.924504 & 0.3653 \\
\hline$\Delta(\operatorname{GSYIH}(-1))$ & -0.050907 & 0.009973 & -5.104 .586 & 0.0000 \\
\hline$\Delta(\mathrm{GSYIH}(-2))$ & -0.031964 & 0.007590 & -4.211 .458 & 0.0004 \\
\hline $\operatorname{ECM}(\mathrm{t}-1)$ & -0.238783 & 0.044702 & -5.341 .674 & 0.0000 \\
\hline \multicolumn{5}{|c|}{ Hata Düzeltme ve ARDL modeline ait tanımsal testler } \\
\hline R-squared & 0.697273 & Jarque-Bera & 0.463937 & $(0.7929)$ \\
\hline Adjusted R-squared & 0.588292 & Ramsey Resset & 3.561 .832 & $(0.0730)$ \\
\hline Durbin-Watson (DW) & 1.806 .996 & Breusch-Pagan-Godfrey & 1.521 .51 & $(0.1729)$ \\
\hline
\end{tabular}

Tablo 9'da ARDL $(4,3,3)$ modelinde, Jarque-Bera (Normallik) testi ile hesaplanan olasılık $(0,792967)$ değeri, 0.05 değerinden büyük olduğu için modeldeki zaman serilerinin normal dağılım gösterdiği tespit edilmiştir. Ramsey Resset test sonucuna göre, hesaplanan F istatistik değeri (3.561.832), $\% 5$ anlamlılık düzeyinde olasılık değerinin (0.0730) olduğu ve olasilık değerinin 0,05 'ten büyük olduğundan dolayı ARDL $(4,3,3)$ modelinde, model kurma hatasının olmadığı tespit edilmiştir. Breusch-Pagan-Godfrey (değişen varyans) testi ile modeldeki zaman serilerin en küçük kareler yöntemiyle elde edilen kalıntıların karesi $\hat{u}_{t}{ }^{2}$ bağımlı değişken olarak alınarak hesaplanan olasılık değerlerinin, 0.05 'ten büyük olmasından dolayı $\mathrm{H}_{0}$ hipotezi reddedilerek zaman serilerinde değişen varyans sorununun olmadığ 1 tespit edilmiştir.

Tablo 9'da ARDL $(4,3,3)$ hata düzeltme modeli, denklem 5'e göre en küçük kareler yöntemiyle kurulur. Hata düzeltme modelinde, hata düzeltme terimi olarak ifaden edilen $\mathrm{ECM}(\mathrm{t}-1)$ 'in hata düzeltme terimi katsayı $\delta\left(\mathrm{ECM}_{\mathrm{t} t}\right.$ 1)) değerinin sonucu tabloda gösterilmektedir. Buna göre hata düzeltme katsayıs1 değeri, $\left.\delta\left(\mathrm{ECM}_{(\mathrm{t}-1)}\right)=1 /|-0,23|\right)$ hesaplama sonucunda k1sa dönemde oluşan dengesizliklerin 4 yılsonunda uzun dönem denge değerine doğru yakınsayacağı sonucu çıkarılmaktadır.

Kısa dönem hata düzeltme teriminin katsayı değerinin pozitif veya 2 'den küçük bir değer alması, uzun dönem dengesinden uzaklaşıldığını gösterir. Modelindeki hata düzeltme katsayı değerinin 0 ile -1 arasında olması uzun dönem denge değerine doğru tek yönlü yakınsamanın olduğu son olarak hata düzeltme katsayı değerinin -1 ile -2 arasında bir değer alması uzun hata 
düzeltme teriminin boyutu küçülen dalgalanmalarla uzun dönem dengesine ulaştığını göstermektedir (Alam ve Quazi, 2003: 97).

ARDL $(4,3,3)$ modelinde Breusch-Godfrey Serial Correlation LM test ile modelde otokerelasyon olup olmadığını anlamak için aşağıda hesaplanan test sonuçları ve tablo değerleri ile ilgili genel olarak bilgilendirme yapılmıştır.

Breusch-Godfrey Serial Correlation LM Test: Breusch-Godfrey (Godfrey 1978) testi, modeldeki kalıntıların farklı gecikmeleri olması durumunda zaman serilerinin serisel korelasyonunu test etmek için kullanılmaktadır (Kisava ve Myovella, 2018: 86).

$$
\begin{aligned}
& Y_{t}=\beta_{1}+\beta_{2} X_{2 t}+\beta_{3} X_{3 t+\cdots \ldots \ldots \ldots . .}+u_{t} \\
& u_{t}=p_{1} u_{t-1}+p_{2} u_{t-2}+\ldots \ldots+p_{p} u_{t-p}+\varepsilon_{t} \\
& u_{t}=u_{t} \text { 'nin } \mathrm{t} \text { döneminde aldığ } 1 \text { yani veriler yıllık olduğu için yıl olarak ifade } \\
& \text { edilir. } \\
& u_{t-1}=u_{t} \text { 'nin bir önceki yılda aldığ } 1 \text { değeri ifade eder. } \\
& Y_{t}=\beta_{1}+\beta_{2} X_{2 t}+\beta_{3} X_{3 t+\ldots}+u_{t} p_{1} u_{t-1}+p_{2} u_{t-2}+\ldots \ldots+p_{p} u_{t-p}+\varepsilon_{t} \quad 8 \\
& \hat{u}_{t}=\alpha_{0}+\alpha_{1} X_{2 t}+\ldots+\alpha_{R} X_{R t}+\alpha_{R+1} \hat{u}_{t-1}+\ldots \ldots \alpha_{R+P} \hat{\mathrm{u}}_{\mathrm{t}-\mathrm{p}} \\
& \mathrm{H}_{0}: p_{1}=p_{2}=\ldots \ldots \ldots \ldots \ldots \ldots \ldots p_{p}=0 \text { otokorelasyon yok }
\end{aligned}
$$

Birinci adım olarak denklem 6'ya göre değişkenler ile hata terimlerinin ardışı gecikmeleri ile en küçük kareler yöntemiyle tahmini regresyon denklemi oluşturularak $\hat{u}_{t}$ elde edilir. Sonraki aşamada en küçük kareler yöntemiyle gecikme sayısı $p$ olacak şekilde olarak denklem 8'de ki gibi model oluşturulur. Denklem 9'da ki modele göre LM istatistiği $(n-p) \mathrm{R}^{2}$ hesaplanır. Hesaplanan LM istatistiği belirli bir anlamlılık düzeyinde $\mathrm{X}_{\mathrm{p}}^{2}$ kritik değerinden büyükse, serisel korelasyonun var olduğu tespit edilir (Asteriou ve Hall, 2011: 159-160).

Tahmini regresyon denkleminde hesaplanan $(n-p) R^{2}$ ile $X_{p}^{2}$ kritik değeri karşılaştırılarak yukarıda denklemlere göre ARDL $(4,3,3)$ modeline ait zaman serilerinin durağan olup olamadığı tespit edilir. Denklem 9'a göre en küçük kareler yöntemiyle tahmini regresyonda bağımlı değişken olarak ût, bağımsız değişken olarak ARDL $(4,3,3)$ modelinde cari sağlık harcamasının GSYİH'ya oranı (CSH), doğumda beklenen yaşam süresi (DBYS), ekonomik büyüme (GSYIH) ve hata terimi kalıntılarının ardışı gecikme değerleri ile modeldeki zaman serilerinde serisel korelasyon, Breusch-Godfrey Serial Correlation LM test ile test edilir. ARDL $(4,3,3)$ modelinde zaman serilerin kalıntılarının gecikme değerleri ile hesaplanan test sonuçları Tablo 10'de sunulmaktadır.

Tablo 10: Breusch-Godfrey Serial Correlation LM Test Sonuçları

\begin{tabular}{llll}
\hline F-statistic & 0.236171 & Prob. F (2,20) & 0.7918 \\
Obs*R-squared & 0.807526 & Prob. Chi-Square (2) & 0.6678
\end{tabular}

$\mathrm{H}_{0}$ (otokorelasyon yok) hipotezi, alternatif $\mathrm{H}_{1}$ hipotezin (serisel korelasyon var) lehine reddedilerek, ARDL $(4,3,3)$ modeline göre zaman serilerilerinin serisel korelasyondan arınmış olduğu sonucuna varılır. BreuschGodfrey Serial Correlation LM Test sonucunda zaman serilerinin durağanlığını doğrulamak için, Q İstatistiği testi uygulanmıştır. Tablo 11'deki Correlogram_Q İstatistiği test sonuçlarında Q İstatistik ve olasıllk (prob) değerleri ve 
otokorelasyon ile kısmi korelasyon korelogram sonuçları incelenerek zaman serilerinin durağan olup olmadığına karar verilir.

Tablo 11: Correlogram-Q İstatistiği Test Sonuçları

\begin{tabular}{|c|c|c|c|c|c|c|}
\hline Autocorrelation & Partial Correlation & & $\mathrm{AC}$ & PAC & Q-Stat & Prob \\
\hline.$|*|$ &.$|*|$. & 1 & 0.086 & 0.086 & 0.2848 & 0.594 \\
\hline.$||$. &. $\mid .1$ & 2 & -0.038 & -0.046 & 0.3412 & 0.843 \\
\hline.$*||$. &.$* 1$ & 3 & -0.112 & -0.105 & 0.8459 & 0.838 \\
\hline$* *||$. & $* *||$. & 4 & -0.266 & -0.254 & 38.026 & 0.433 \\
\hline.$||$. &. $\mid .1$ & 5 & -0.035 & -0.006 & 38.547 & 0.571 \\
\hline$* *||$. & ****|. | & 6 & -0.303 & -0.362 & 79.491 & 0.242 \\
\hline.$||$. & .1 .1 & 7 & -0.005 & -0.027 & 79.503 & 0.337 \\
\hline.$* 1$ & $* *||$. & 8 & -0.091 & -0.276 & 83.483 & 0.400 \\
\hline.$|* . \quad|$ & $.\left.\right|^{*} . \quad \mid$ & 9 & 0.132 & 0.080 & 92.166 & 0.418 \\
\hline$.\left.\right|^{* *} \quad \mid$ &.$|*|$. & 10 & 0.320 & 0.088 & 14.508 & 0.151 \\
\hline.$||$. & $*||$. & 11 & -0.020 & -0.083 & 14.529 & 0.205 \\
\hline.$||$. & **| | & 12 & 0.004 & -0.146 & 14.531 & 0.268 \\
\hline.$||$. & $.\left.\right|^{*} . \quad \mid$ & 13 & 0.025 & 0.152 & 14.568 & 0.335 \\
\hline .*1. | & $* *||$. & 14 & -0.123 & -0.210 & 15.502 & 0.345 \\
\hline$. * 1 . \quad 1$ & .1 .1 & 15 & -0.109 & -0.045 & 16.269 & 0.364 \\
\hline$. * \mid$ &.$* 1$ & 16 & -0.147 & -0.134 & 17.752 & 0.339 \\
\hline
\end{tabular}

Tablo 11'de Korelogram-Q-istatistikleri ile ARDL (4,3,3) modelindeki kalıntıların, otokorelasyon ve kısmi korelasyon fonksiyonları gösterilmektedir. Tabloda kalıntıların tüm gecikmelerdeki otokorelasyon ve kısmi korelasyon değerlerinin sıfıra yakın olduğu ve Q- istatistik değerlerinin büyük olduğu, Qistatistik olasılık değerlerin 0,05 'den büyük olması ile zaman serilerinin durağan olduğu diğer bir ifadeyle serisel korelasyondan arınmış olduğu kanitlanmaktadır.

Değişkenlere ilişkin yapısal kırılmanın olup olmadığını belirlemek, modelin kararlığını araştırmak için geri dönüşlü hata terimlerinin karelerini kullanarak değişkenlere ilişkin yapısal kırılmaları belirlemek amacıyla Cusum ve CusumsQ grafiklerinden yararlanılmıştır (Akel ve Gazel, 2014:36).

Brown, Durbin ve Evans (1975) tarafından geliştirilen, Cusum ve CusumsQ grafikleri ile uzun dönem katsayıları ve kısa dönem dinamikleri incelenmektedir. Cusum istatistiği \%5 anlam düzeyinde kritik çizgi arasında kalırsa, Brown, Durbin ve Evans (1975) geliştirdikleri denkleme göre, hata düzeltme modelindeki katsayıların istikrarlı olmasını ifade eden Ho hipotezi reddedilemez (Bahmani-Oskooee, 2002: 153-154). ARDL (4,3,3) modelinde değişkenlere ilişkin Cusum ve CusumsQ grafikleri Şekil 4'te gösterilmektedir. 

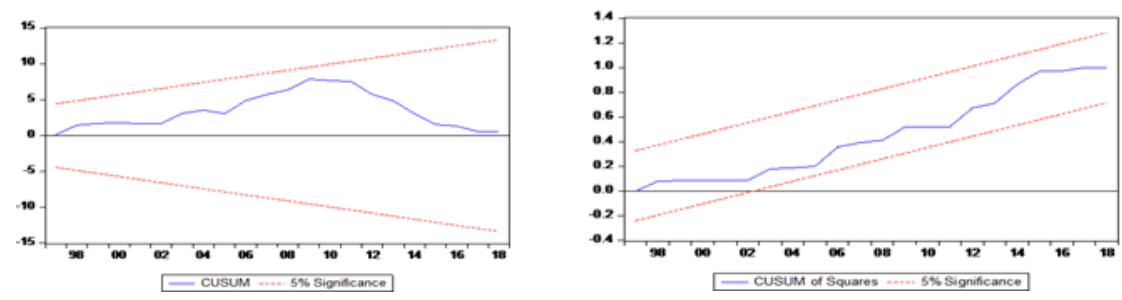

Şekil 4: Cusum ve CusumsQ Grafikleri

Şekil 4'te görüldüğü gibi, Cusum ve CusumsQ grafikleri \%5 anlamlılık düzeyinde kritik sınırlar içinde kalması ile katsayıların durağanlığını ifade eden $\mathrm{H}_{0}$ hipotezi reddedilmeyerek modeldeki katsayıların istikrarlı olduğu sonucu çıkarılır. Ayrıca Cusum ve CusumsQ grafikleri incelendiğinde ARDL $(4,3,3)$ modeline göre analizi yapılan değişkenlere ilişkin yapısal kırılmanın olmadığ sonucuna varılmaktadır.

\section{Sonuç}

Sağlık ekonomisinde ortaya çıkan yeni hastalıklar, öngörülemeyen salgınlar, doğumda beklenen yaşam süresinin artmasına bağlı olarak insan ömrünün uzaması ile özellikle yaşlılarda görülen kronik rahatsızlıklar ve yaşlılığa bağlı olarak gelişen diğer hastalıklarla beraber sağlık alanında gelişen teknoloji ile yapay zekâ alanındaki gelişmeye paralel olarak tıp alanında ilerleme ve diğer faktörlerle sağlık harcamaları her geçen yıl giderek artan bir oranla bütçeden önemli pay almaktadır. Çalışmada cari sağlık harcamasının gayri safi yurtiçi hasılaya oranı, toplam sağlık harcamasında en fazla yüzdeye sahip olduğundan dolayı bağımlı değişken olarak alınıp ekonomik büyüme ve doğumda beklenen yaşam süresi bağımsız değişkenleri ile analiz edilmiştir. Analiz sonuçları, doğumda beklenen yaşam süresindeki \%1'lik artışın, cari sağlık harcamasının gayri safi yurtiçi hasılaya oranını yaklaşık \%31,15 oranda arttırdığ 1 yönündedir. $\mathrm{Bu}$ artış, sağlık hizmetinin genel olarak kamu sağl1k sunucuları tarafından sağlandığı ve finansmanının büyük bir oranı kamu kurumu olan SGK tarafından karşılanması temeline dayanmaktadır.

Türkiye'de uygulanan sağlık reformları ve sağlık politikaları ile bireylerin sağlık sunucularına erişimdeki kolaylıkla sağlık hizmetini rahatlıkla alması ve uygulanan genel sağlık sigortası ile kamu sağlık harcamaları oranında büyük bir artış yaşandığı görülmektedir. Sosyal devlet anlayışı temelinde sağlık harcamalarının kamu olarak hizmet vermesi ile sağlığa olan talebin arttığı gözlenmektedir. Çalışmada ekonomik büyümedeki \%1'lik artışın, cari sağlık harcamasının GSYİH'ya oranını yaklaşı $\% 0.28$ oranda arttırdığı tespit edilmiştir. Ekonomik büyüme oranındaki artışın cari sağlık harcamasının GSYİH'ya oranını pozitif yönde etkilediği ve doğumda beklenen yaşam süresindeki artışın, cari sağlık harcamasının gayri safi yurtiçi payını önemli ölçüde artırdığı yapılan analiz sonucunda tespit edilmiştir.

Ülkelerin ekonomik yönden gelişmesinde önemli unsuru olarak görülen doğumda beklenen yaşam süresi en önemli sağlık çıtısı olarak düşünülmektedir. Gelişmiş ülkeler yaşam süresine göre kıyaslandığında az gelişmiş ülkelere göre ileride olduğu görülmektedir. $\mathrm{Bu}$ durum ekonomik büyüme parametreleri ile sağlık göstergelerinin analizinde önem arz etmektedir. İktisadi yazında sağlık harcamalarının belirleyicisi olarak görülen doğumda 
beklenen yaşam süresi ile iktisadi göstergeler arasındaki çalışmalara daha fazla yer verildiği görülmektedir.

Türkiye'de artan yaşam süresinin sağlık harcamaları ve ekonomik büyüme üzerine olan pozitif etkisi nedeniyle; gelișen teknoloji ile altyapının sağlam temeller üzerine oturtulması, sağlık alanında gelişen teknoloji (yapay zekâ) kullanımının artmasına bağlı olarak oluşabilecek komplikasyonların en aza indirgenmesinin öngörülmesi ile sağlık alanında gereksiz harcamalardan kaçınılarak aynı zamanda ekonomik büyümeye katkı sağlayacağı düşünülmektedir.

Çıkar Çatışması Beyanı / Conflicts of Interest Statement:

Çalışmada çıkar çatışması bulunmamaktadır.

There is no conflict of interest in the study.

Maddi Destek / Financial Support:

$\mathrm{Bu}$ çalışmada herhangi bir fon veya maddi destekten yararlanılmamıştır.

No funding or financial support was used in this study.

Yazar Katkıları / Contribution Rate of the Authors:

Fikir: FA; Tasarım: FA; Veri Toplama: FA; Kaynak Tarama: FA; Analiz ve Yorum: FA; Makalenin Yazımı: FA.

Idea: FA; Design: FA; Data Collecting: FA; Literature Review: FA; Analysis and Discussion: FA; Writing: FA.

(!) Yazar/yazarlar bu çalıșmanın tüm süreçlerinin araştırma ve yayın etiğine uygun olduğunu, etik kurallara ve bilimsel atıf gösterme ilkelerine uyduğunu beyan etmiştir. Aksi bir durumda Medeniyet Araştırmaları Dergisi sorumlu değildir.

(!) The author/authors declared that all processes of this study are in accordance with research and publication ethics, and comply with ethical rules and principles of scientific citation. Otherwise, the Journal of Civilization Studies is not responsible.

\section{Kaynakça}

Akar, S. (2014). Türkiye'de Sağlık Harcamaları, Sağlık Harcamalarının Nisbi Fiyatı ve Ekonomik Büyüme Arasındaki İlişkinin İncelenmesi. Yönetim ve Ekonomi, 21(1), 311-322. https://doi.org/10.18657/yecbu.70940

Akel, V., ve Gazel, S. (2014). Döviz Kurları ile Bıst Sanayi Endeksi Arasındaki Eşbütünleşme İlişkisi: Bir ADRL Sınır Testi Yaklaşımı. Erciyes Üniversitesi İktisadi ve İdari Bilimler Fakültesi Dergisi, 44, 23-41.

Alam, I., ve Quazi, R. (2003). Determinants of Capital Flight: an Econometric Case Study of Bangladesh. International Review of Applied Economics, 17(1), 85-103. https://doi.org/10.1080/713673164

Asteriou, D., ve Hall, S. G. (2011). Applied Econometrics.

Atasever, M. (2018). Türkiye'de Sağlık Hizmetlerinin Finansmanı ve Sağlık Harcamalarının Gelişimi. 34.

Aydın, B. (2020). İktisadi Göstergelerin Beklenen Yaşam Süresi Üzerindeki Etkileri: Panel Veri Analizi. Istanbul Journal of Economics / Istanbul Iktisat Dergisi, $\quad 70(1), \quad 163-181$. https://doi.org/10.26650/ISTJECON2019-002 
Bahmani-Oskooee, M. (2002). Long-Run Demand for Money in Hong Kong: An Application of the ARDL Model. International Journal of Business and Economics, 1(2), 147-155.

Boz, C., ve Aslan, Ö. (2018). Türkiye de 1980-2014 Yılları Arasında Kişi Başı Kamu Sağlık Harcamaları ile Kişi Başı Gayri Safi Yurt İçi Hâsıla Arasındaki İlişkinin İncelenmesi. Sosyal Güvence Dergisi, 7(14), 127. https://doi.org/10.21441/sguz.2018.67

Boz, C., Taş, N., ve Önder, E. (2020). The Impacts of Aging, Income and Urbanization on Health Expenditures: A Panel Regression Analysis for OECD Countries. Türkiye Halk Sağlı̆̆l Dergisi, 18(1), 1-9. https://doi.org/10.20518/tjph.426494

Çelik, A. (2020). G20 Ülkelerinde Sağlık Harcamalarının Ekonomik Büyüme Üzerindeki Etkisinin Analizi. Yönetim ve Ekonomi: Celal Bayar Üniversitesi Iktisadi ve İdari Bilimler Fakültesi Dergisi, 27(1), 1-20. https://doi.org/10.18657/yonveek.594695

Çeştepe, H., Yıldırım, E., ve Yıldız, H. (2020). Türkiye'de Sağlığın Ekonomik Büyümeye Etkisi: 81 İl Düzeyinde Panel GGM Kanitları. Uluslararasi Íktisadi ve İdari İncelemeler Dergisi, 28, 175-192. https://doi.org/10.18092/ulikidince.718228

Çetin, M., ve Ecevit, E. (2010). Sağlık Harcamalarının Ekonomik Büyüme Üzerindeki Etkisi: OECD Ülkeleri Üzerine Bir Panel Analizi. Doğuş Üniversitesi Dergisi, 11(2), 166-182.

Çoban, H. (2009). Sağlık Ekonomisi ve Türkiye'de Sağllk Hizmetlerinin Yeniden Yapılandırılması [Doktora Tezi]. Dokuz Eylül Üniversitesi.

Daştan, İ., ve Çetinkaya, V. (2015). OECD Ülkeleri ve Türkiye'nin Sağlık Sistemleri, Sağlık Harcamaları ve Sağlık Göstergeleri Karşılaştırması. Sosyal güvenlik Dergisi, 5(1), 104-134.

Dreger, C., ve Reimers, H.-E. (2005). Health Care Expenditures in OECD Countries: A Panel Unit Root and Cointegration Analysis. IZA Discussion Papers, No. 1469.

Engle, R. F., Granger, C. W. (1987). Cointegration and Error Correction: Representation, Estimation and Testing. Econometrica, 55(2), 251276.

Erdoğan, S., ve Bozkurt, H. (2008). Türkiye 'de Yaşam Beklentisi-Ekonomik Büyüme İlişkisi: ADRL Modeli ile Bir Analiz. Knowledge Management, 3(1), 25-38.

Granger, C.W.J., ve Newbold, P. (1974). Spurious Regressions in Econometrics. Journal of Econometrics, 2, 111-120.

Güven, D., Şimşek, T., ve Güven, A. (2018). Sağlık Yönetimi Kapsamında Sağlık Harcamalarının Ekonomik Büyüme Üzerine Etkisi: MENA Ülkeleri Üzerine Bir Panel Regresyon Analizi. Sosyoekonomi, 26(37), 33-55. https://doi.org/10.17233/sosyoekonomi.2018.03.02

Güvercin, A., Mil, H. İ., ve Tarım, B. (2016). Sağlık Hizmetlerinin Finansmanı ve Sosyal Güvenlik Kurumu (SGK). Bartın Üniversitesi I.I.B.F. Dergisi, 7(13), 80-94.

Hayaloğlu, P., ve Bal, H. Ç. (2015). Üst Orta Gelirli Ülkelerde Sağlık Harcamaları ve Ekonomik Büyüme İlişkisi. İşletme ve İktisat Çalışmaları Dergisi, 3(2), 35-44. 
Heshmati, A. (2001). On The Causality Between GDP and Health Care Expenditure in Augmented Solow Growth Model. SSE/EFI Working Paper Series in Economics and Finance, No. 423, 423, 1-19.

Istaiteyeh, R. M. S. (2017). Economic and Social Factors in Shaping Jordan's Life Expectancy: Empirical Analysis (1990-2014). Advances in Management and Applied Economics, 7(5), 45-59.

Jaba, E., Balan, C. B., ve Robu, I.-B. (2014). The Relationship Between Life Expectancy at Birth and Health Expenditures Estimated by a Crosscountry and Time-series Analysis. Procedia Economics and Finance, 108-114. https://doi.org/10.1016/S2212-5671(14)00454-7

Johansen, S. (1988). Statistical Analysis of Cointegration Vectors. Journal of Economics Dynamic and Control, 12(2-3), 231-254.

Kılıç, N. Ö., ve Beşer, M. (2018). Sağlık Harcamalarının Ekonomik Büyüme Üzerindeki Etkileri: Merkezi ve Doğu Avrupa (CEEC) Ülkeleri Üzerine Panel Veri Analizi. Süleyman Demirel Üniversitesi İktisadi ve İdari Bilimler Fakültesi Dergisi, 23(2), 373-382.

Kisava, Z. S., ve Myovella, G. A. (2018). Budget Deficit and Inflation in Tanzania: ARDL Bound Test Approach. Business, Economics and Finance $\quad-J B E F, \quad 7(1), \quad 83-88$. https://doi.org/10.17261/Pressacademia.2018.797

Konak, A. (2020). Türkiye'de İhracat ve İstihdamın Ekonomik Büyüme Üzerindeki Etkisi: ADRL Sınır Testi ile Yaklaşımı. Yönetim Ekonomi Edebiyat İslami ve Politik Bilimler Dergisi, 5(1), 56-74. https://doi.org/10.24013/jomelips.730317

Linden, M., ve Ray, D. (2017). Life expectancy effects of public and private health expenditures in OECD countries 1970-2012: Panel time series approach. Economic Analysis and Policy, 56, 1-25. https://doi.org/10.1016/j.eap.2017.06.005

Monsef, A., ve Mehrjardi, A. S. (2015). Determinants of Life Expectancy: A Panel Data Approach. Asian Economic and Financial Review, 5(11), 1251-1257. https://doi.org/10.18488/journal.aefr/2015.5.11/102.11.1251.1257

Mossialos, E., ve Thomson, S. M. S. (2002). Voluntary Health Insurance in the European Union: A Critical Assessment. International Journal of Health Services, 32(1), 19-88. https://doi.org/10.2190/K6BP-3H1RL41M-HVGE.

Narayan, P.K. (2005). The Savings and Investment Nexus for China: Evidence from

Cointegration Test. Applied Economics. 91, 1979-1990.

Narayan, P. K., ve Smyth, R. (2006). What Determines Migration Flows From Low-Income to High-Income Countries? An Empirical Investigation of FIJI-U.S Migration 1972-2001. Contemporary Economic Policy, 24(2), 332-342.

Özkan, G., ve Zengin, G. (2018). Sağlık Harcamaları Ekonomik Büyüme İlişkisi: OECD Ülkeleri Üzerine Panel Veri Analizi (2000-2015). Sosyal Bilimler Dergisi, 8(16), 16.

Polat, M., ve Gemici, E. (2017). Analysıs of The Relationshıp Between Bist and Brics Stock Markets in Terms of Portfolio Diversification: Cointegration Analysis with ADRL Boundary Test. Journal of 
Economics, Finance and Accounting, 4(4), 393-403. https://doi.org/10.17261/Pressacademia.2017.749

Pesaran, M. H., Shin, Y., ve Smith, R. J. (2001). Bounds Testing Approaches to the Analysis of Level Relationships. Journal of Applied Econometrics, 16(3), 289-326.

Sayı11, U., Aksu Sayman, Ö., Vehid, S., Köksal, S. S., ve Erginöz, E. (2017). Türkiye ve OECD Ülkelerinin Sağlik Göstergeleri ve Sağlık Harcamalarının Karşılaştırılması. Online Türk Sağllk Bilimleri Dergisi, 2(3), 1-12. https://doi.org/10.26453/otjhs.321742

Sever, E., ve İğdeli, A. (2019). Sağlık Harcamaları, Sağlık Çıktıları ve Ekonomik Büyüme İlişkisi: Türkiye Örneği. Akademik Araştırmalar ve Çalışmalar Dergisi, 11(20), 246-259.

Şaşmaz, M. Ü., Odabaş, H., ve Yayla, Y. E. (2019). OECD Ülkelerinde Sağlık Harcamaları ile Kalkınma Arasındaki İlişki: Panel Veri Analizi. Yönetim ve Ekonomi: Celal Bayar Üniversitesi Iktisadi ve İdari Bilimler Fakültesi Dergisi, 26(3), 852-866. https://doi.org/10.18657/yonveek.544425

Şeyma Koca, G. (2018). Sağlık Hizmetleri Finansmanında Satın Alma ve Ülke Örnekleri. Social Sciences Studies Journal, 4(24), 5043-5051. https://doi.org/10.26449/sssj.970

Taban, S. (2006). Türkiye'de Sağlık ve Ekonomik Büyüme Arasındaki Nedensellik İlişkisi. Sosyo Ekonomi, 2, 31-46.

Teker, D., Teker, S., ve Sönmez, M. (2012). Ekonomik Değişkenlerin Kadın ve Erkeğin Yaşam Süresine Etkisi. Journal of Business Research, 4(3), 118-126.

Tıraş, H. H., ve Özbek, S. (2020). OECD Ülkelerinde Doğuşta Yaşam Beklentisinin Belirleyicilerinin Ekonometrik Analizi. Business \& Management Studies: An International Journal, 8(3), 2893-2923. https://doi.org/10.15295/bmij.v8i3.1542

Tüylüoğlu, Ş., ve Tekin, M. (2009). Gelir Düzeyi ve Sağlık Harcamalarının Beklenen Yaşam Süresi ve Bebek Ölüm Oranı Üzerindeki Etkileri. Çukurova Üniversitesi IIBBF Dergisi, 13(1), 1-31.

Uçan, O., ve Atay, S. (2016). Türkiye'de Sağlık Harcamaları ve Büyüme Arasındaki İlişki Üzerine Bir İnceleme. Niğde Üniversitesi İktisadi ve İdari Bilimler Fakültesi Dergisi, 9(3), 215-222.

Uzgören, E., ve Akalin, G. (2016). Doğrudan Yabanc1 Yatırımların Belirleyicileri: ADRL Sınır Testi Yaklaşımı. Sosyal Bilimler Dergisi, 49, 63-77.

Wild, C., ve Gibis, B. (2003). Evaluations of Health Interventions in Social Insurance-Based Countries: Germany, the Netherlands, and Austria. Health Policy, 63(2), 187-196. https://doi.org/10.1016/S01688510(02)00065-9

Yenimahalleli Yaşar, G. (2010). Sağlık Finansmanını Değerlendirme Ölçütleri. Ankara Üniversitesi Dikimevi Sağlık Hizmetleri Meslek Yüksekokulu Dergisi, 9(1), 31-43.

Yılmaz, G. (2018). Türkiye'de Sağlık Sisteminde Reformlar ve Politika Transferi. Sosyal Politika Çalışmaları Dergisi, 18(41), 180-206. https://doi.org/10.21560/spcd.vi.363875 
Yumuşak, İ. G., ve Yıldırım, D. Ç. (2009). Sağlık Harcamalarının İktisadi Büyüme İlişkisi Üzerine Ekonometrik Bir İnceleme. Bilgi Ekonomisi ve Yönetimi Dergisi, 4(1), 57-70.

Yurdadoğ, V. (2007). Türkiye'de Sağlık Harcamalarının Finansmanı ve Analizi. Ç.Ü. Sosyal Bilimler Enstitüsü Dergisi, 16(1), 591-610.

\section{İnternet Kaynakları}

https://data.oecd.org/healthstat/life-expectancy-at-birth.htm. Erişim Tarihi: 20.12.2020

https://data.oecd.org/healthres/health-spending.htm. Erişim Tarihi: 20.12.2020

https://data.worldbank.org/indicator/. Erişim Tarihi: 15.12.2020

https://data.worldbank.org/country/turkey. Erișim Tarihi: 15.12.2020 